Article

\title{
Geochronology and Genesis of the Xitian W-Sn Polymetallic Deposit in Eastern Hunan Province, South China: Evidence from Zircon U-Pb and Muscovite Ar-Ar Dating, Petrochemistry, and Wolframite $\mathrm{Sr}-\mathrm{Nd}-\mathrm{Pb}$ Isotopes
}

\author{
Jingya Cao ${ }^{1,2,3}\left(\mathbb{D}\right.$, Qianhong Wu ${ }^{1, *}$, Xiaoyong Yang ${ }^{2, *}$, Hua Kong ${ }^{1}$, Huan Li 1 (D), \\ Xiaoshuang $\mathrm{Xi}^{1}{ }^{1}$, Qianfeng Huang ${ }^{1}$ and Biao Liu ${ }^{1}$ \\ 1 Key Laboratory of Metallogenic Prediction of Nonferrous Metals and Geological Environment Monitoring \\ (Central South University), Ministry of Education, Changsha 410083, China; jingyacao@126.com (J.C.); \\ konghua2006@126.com (H.K.); lihuan@csu.edu.cn (H.L.); xiyiyun@sina.com (X.X.); \\ hqianfeng@gmail.com (Q.H.); liubiaoznuedu@163.com (B.L.) \\ 2 CAS Key laboratory of Crust-Mantle Materials and Environments, University of Science and Technology of \\ China, Hefei 230026, China \\ 3 Geological Survey of Anhui Province, Hefei 230001, China \\ * Correspondence: qhwu19@163.com (Q.W.); xyyang@ustc.edu.cn (X.Y.)
}

Received: 6 February 2018; Accepted: 24 February 2018; Published: 8 March 2018

\begin{abstract}
The recently explored Xitian tungsten-tin (W-Sn) polymetallic ore field, located in Hunan province, South China, is one of the largest ore fields in the Nanling Range (NLR). Two major metallogenic types appeared in this ore field, skarn- and quartz vein-type. They are distributed within Longshang, Heshuxia, Shaiheling, Hejiangkou, Goudalan, and so on. Hydrothermal zircons from two altered granites yielded U-Pb ages of $152.8 \pm 1.1 \mathrm{Ma}$, and $226.0 \pm 2.8 \mathrm{Ma}$, respectively. Two muscovite samples from ore-bearing quartz vein yielded ${ }^{40} \mathrm{Ar} /{ }^{39} \mathrm{Ar}$ plateau ages of $156.6 \pm 0.7 \mathrm{Ma}, 149.5 \pm 0.8 \mathrm{Ma}$, respectively. Combined with the geological evidence, two metallogenic events are proposed in the Xitian ore field, with skarn-type W-Sn mineralization in Late Triassic (Indosinian) and quartz vein/greisen type W-Sn mineralization in Late Jurassic (Yanshanian). The relatively low $\mathrm{Ce} / \mathrm{Ce}^{*}$ ratios and high $\mathrm{Y} / \mathrm{Ho}$ ratios in zircons from two altered granites indicate that the hydrothermal fluids of two metallogenic events are characterized by low oxygen fugacities and enrichment in F. The similar chondrite-normalized patterns between the skarn and Xitian Indosinian granites and $\mathrm{Sr}-\mathrm{Nd}-\mathrm{Pb}$ isotopic compositions of wolframite suggest that the metal sources for both types W-Sn mineralization are derived from a crustal source.
\end{abstract}

Keywords: zircon $\mathrm{U}-\mathrm{Pb}$; muscovite $\mathrm{Ar}-\mathrm{Ar}$; wolframite $\mathrm{Sr}-\mathrm{Nd}-\mathrm{Pb}$ isotopes; Xitian $\mathrm{W}-\mathrm{Sn}$ deposit; Eastern Hunan

\section{Introduction}

Tungsten (W) and tin (Sn) are important metals in many aspects of industrial manufacture. Accompanied by the greater demand for W-Sn, the study and exploitation of W-Sn deposits have long been a hot topic [1-13]. China holds the largest resources of W and Sn in terms of production and reserves, and their reserves have accounted for ca. $58 \%$ and ca. $31 \%$ in the world, respectively [14]. In China, more than $83 \%$ of the $\mathrm{W}$ and $63 \%$ of the Sn reserves are in the Nanling region [15]. The Nanling region is famous for its large-scale and multi-stage magmatism and abundant $\mathrm{W}, \mathrm{Sn}$ and other rare-metal resources and reserves [2,3,15-22]. Previous studies have revealed the presence of 
many large W-Sn polymetallic deposits in this region, such as Shizhuyuan, Dajishan, Xianghualing, Xihuashan, and Xitian (Figure 1; [17-19,23-25]. Furthermore, they are closely related to the Mesozoic granitic intrusions, on both temporal and spatial scales [12,23,26-28]. Since the 1990s, a considerable amount of high-precision data of rock- and ore-forming ages have been obtained from the Nanling range with the help of progressive dating technologies, such as zircon $\mathrm{U}-\mathrm{Pb}$, molybdenite Re-Os, and mica ${ }^{40} \mathrm{Ar}^{-39} \mathrm{Ar}$ dating methods, and most of these ages show that these deposits were formed in late Mesozoic (Yanshanian), such as Shizhuyuan (149 \pm 2 Ma; [29]), Xianghualing (156 $\pm 4 \mathrm{Ma}$; [24]), Xihuashan (157.8 \pm 0.9 Ma; [18]), Dajishan (161.1 $\pm 1.3 \mathrm{Ma}$; [30]), Taoxikeng (154.4 $\pm 3.8 \mathrm{Ma}$; [17]) and Xitian (151.8 $\pm 1.4 \mathrm{Ma}$; [19]). Recently, some new data of metallogenic age for the W-Sn deposits in this area are proven to be early Mesozoic (Indosinian), such as Wangxianling (220.6 $\pm 1.1 \mathrm{Ma}$; [31]), Hehuaping (224.0 $\pm 1.9 \mathrm{Ma}$; [32]), and Limu (214.1 $\pm 1.9 \mathrm{Ma}$; [33]). This evidence demonstrated that two periods of metallogenetic events existed in the Nanling region. However, further studies on the mineral genetic epoch for the deposits are required, especially for these deposits with multiple phase-intrusive activities.

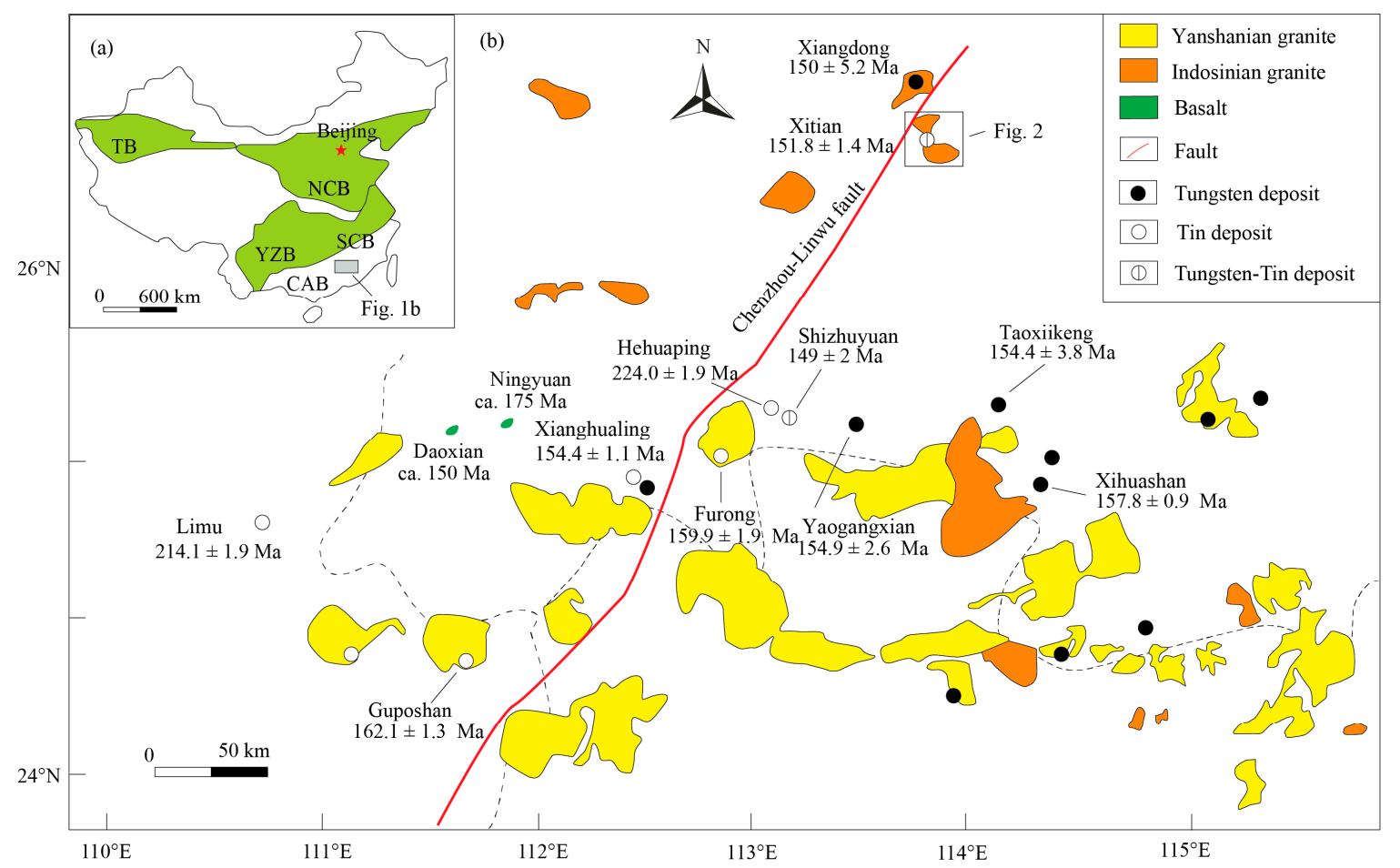

Figure 1. (a) Geological sketch map of China; (b) Geological sketch map of the Nanling region (modified from [2]), showing the distribution of granitic plutons, basalts, and related W-Sn deposits and their geochronological data compiled from [17-19,21,29,31-37]. TB: Tarim block; CAB: Cathaysian Block; NCB: North China Block; SCB: South China Block; YZB: Yangtze Block.

The Xitian W-Sn polymetallic ore field, located in the middle of the Nanling region, is one of the largest newly discovered ore fields in recent years (Figure 2). A large number of studies have been carried out in the Xitian area by geochemical and isotopic methods, and these studies have shown that the formation of this deposit is genetically related to the Xitian pluton [19,28,38,39]. Many dating technologies have been applied to study the emplacement age of this pluton and metallogenic age of this deposit, including LA-ICP-MS, and ion probe by either SHRIMP or CAMECA zircon U-Pb, mica and cassiterite ${ }^{40} \mathrm{Ar}-{ }^{39} \mathrm{Ar}$, and molybdenite Re-Os isotopic techniques [19,40-42]. These precise data provide detailed chronological constraints on the emplacement age of the Xitian pluton and for the time interval between W-Sn mineralization of the Xitian deposit. The majority of these chronological data show that the Xitian pluton could be subdivided into the Late Triassic (Indosinian) granites 
(230-220 Ma) and the Late Jurassic (Yanshanian) granites (160-140 Ma), and the time interval for W-Sn mineralization is 160-150 Ma. From the above-mentioned evidence, it seems that the formation of this ore field is attributed to Yanshanian magmatic activity. Deng et al. [43] obtained a molybdenite Re-Os age of $225.5 \pm 3.6 \mathrm{Ma}$ from altered granites in the Indosinian granitic batholith, indicating a possibility for the Indosinian mineralization event in the Xitian ore field; however, this age may not represent the age of the large-scale skarn-type W-Sn mineralization in the Xitian ore field. It was proposed that the skarn occurred in the contact zone between the Yanshanian granites and the Devonian dolomitic limestone [19]. However, recent studies show that the granites belong to Indosinian granites rather than Yanshanian granites [34]. Therefore, is the skarn type ore body related to the Indosinian granites, rather than to the Yanshanian granites? Ore-forming age of some deposits in the Xitian ore field is still in doubt; for example, the Hejiangkou deposit. In this study, we display the results of zircon U-Pb dating, zircon compositions, muscovite ${ }^{40} \mathrm{Ar}^{39} \mathrm{Ar}$ dating, skarn geochemistry, and wolframite $\mathrm{Sr}-\mathrm{Nd}-\mathrm{Pb}$ isotopic compositions, with the aims of constraining the time interval between mineralization and the emplacement of associated granitic rocks, outlining the genetic relationship between two episodes of granitic magmatism and two types of W-Sn mineralization, and probing into the genesis of the two types of W-Sn mineralization in the Xitian ore field.

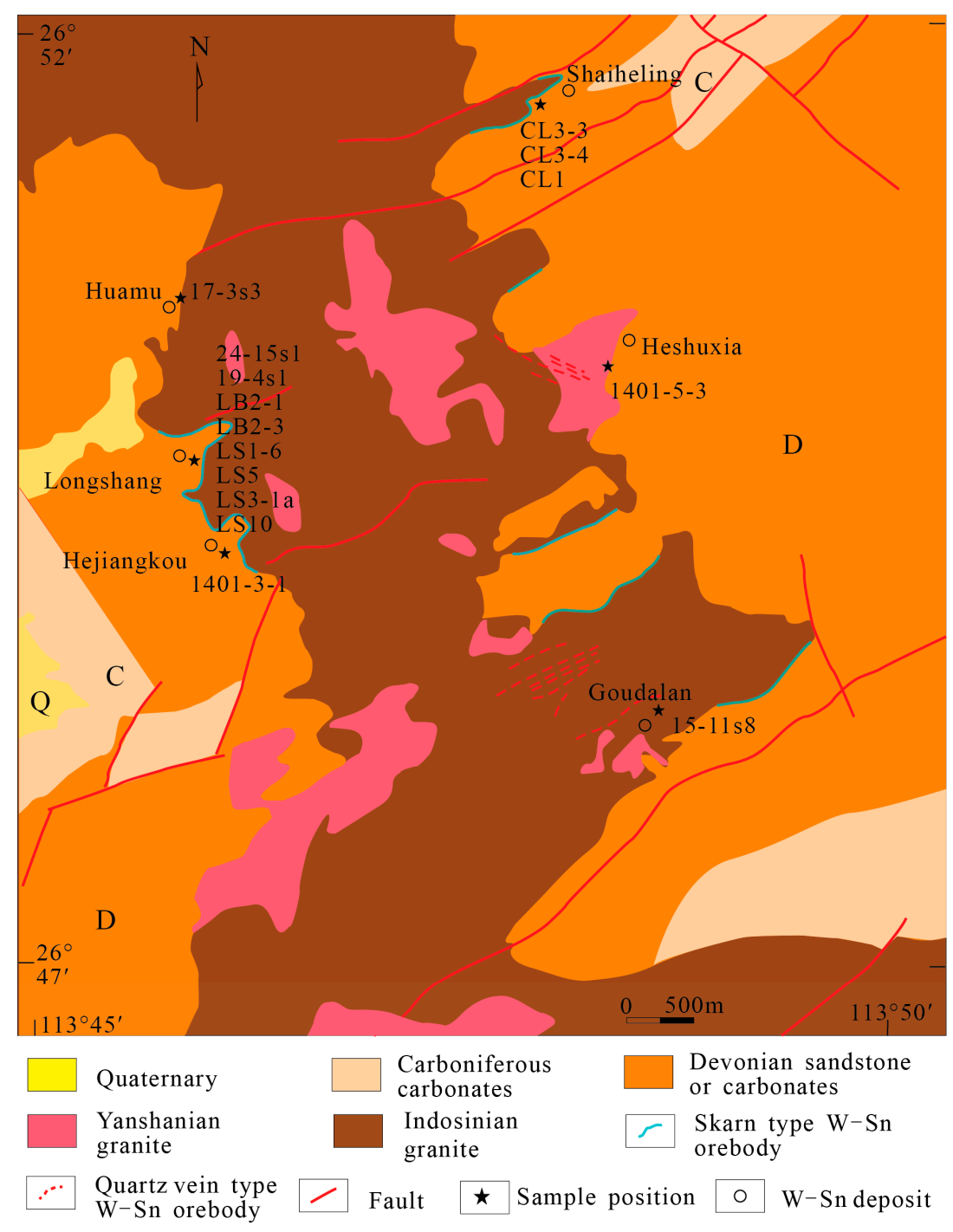

Figure 2. Schematic geological map of the Xitian W-Sn ore field showing the location of samples (modified from [44]). 


\section{Geological Setting}

The South China Block (SCB) was formed by the amalgamation of the Yangtze Block (YZB) to the northwest and the Cathaysian Block (CAB) to the southeast at ca. $820 \mathrm{Ma}$ (Figure 1a; [45]). The Nanling region, located in the central section of SCB, is comprised of Guangxi, Guangdong, Hunan, and Jiangxi province occupying an area of $170,000 \mathrm{~km}^{2}$ [46]. This region has undergone several significant tectonic-magmatic events, the most famous of which are the Indosinian and Yanshanian tectonic events during the Mesozoic [47-53]. Due to the superior metallogenic geotectonic setting, it is characterized by widespread igneous rocks and numerous large-scale W-Sn polymetallic deposits $[2,3,16,20,54,55]$. The basement of the Nanling region consists of weakly metamorphosed Precambrian, late Paleozoic sedimentary strata which are mainly Devonian and Carboniferous carbonate rocks, and lesser amounts of Upper Triassic to Tertiary sandstone and siltstone [2,46]. The regional fault is the NE-trending Chenzhou-Linwu fault which controls the spatial distribution of the granitic intrusions and numerous $\mathrm{W}-\mathrm{Sn}$ polymetallic deposits associated with the granitic magma activities (Figure 1b; $[56,57]$ ). Numerous granitic intrusions were emplaced in this region, most of which are Indosinian and Yanshanian pluton, and these granites are mostly peraluminous, calc-alkaline and remelted granites $[12,23,27,28,58,59]$.

The Xitian ore field, located in Chaling, Hunan province, is characterized by intensive and widely distributed granitoids associated with numerous non-ferrous and rare-metal minerals of Mesozoic age $[19,39,44,60]$.

\subsection{Sedimentary Rocks}

The strata outcropping in the Xitian area are Ordovician, Devonian, Carboniferous, and Cretaceous sedimentary rocks, among which the middle to upper Devonian and Carboniferous rocks are dominant (Figure 2). Lying unconformably on Ordovician metasedimentary rocks, the Devonian strata can be subdivided into the Middle Devonian Tiaomajian and Qiziqiao Formations, and the upper Devonian Shetianqiao and Xikuangshan Formations [61]. The Tiaomajian formation, 35-42 $\mathrm{m}$ in thickness, consists of conglomerate-bearing quartzite. The Qiziqiao formation, over $200 \mathrm{~m}$ thick, comprises impure carbonate rocks and arenaceous shale, and is the typical ore reservoirs of the Xitian ore field. The Shetianqiao formation is up to $500 \mathrm{~m}$ thick, composed of quartz sandstone and argillaceous siltstone. The Xikuangshan formation, 110-130 $\mathrm{m}$ in thickness, are mainly quartz sandstone, arenaceous shale and nodular limestones. The Carboniferous Yanguan formation which is about $275 \mathrm{~m}$ in thickness, mainly consists of sandshale and siltstone.

\subsection{Structure}

The Xitian ore field is located to the east of the NE-trending Chenzhou-Linwu deep fault (Figure 1b), which is considered to be the boundary between the Yangtze Block and Cathaysian Block $[56,57,62]$. The tectonic framework of this region is controlled mainly by two trends of faults which are approximately NE-, nearly SN- and NW-trending. The NE-trending faults are the larger in scale, and some of these faults are truncated by the NW- and/or SN trending-faults (Figure 2). The NE-trending faults are the main ore-controlling faults in Xitian ore field, with $2-13 \mathrm{~km}$ in outcropped length, $60-70^{\circ}$ in angle of trend, and $60-85^{\circ}$ in angle of dip [60]. The nearly SN-trending faults are also important ore-bearing structures, including a series of NNW-, $\mathrm{SN}$ - and NNE-trending small faults [60]. The NW-trending faults are about $1.5-8.0 \mathrm{~km}$ in outcropped length, with a dip of NNE and large inclined angle [60].

\subsection{Igneous Rocks}

The Xitian pluton, occupying an area of $\sim 240 \mathrm{~km}^{2}$, are intruded into Paleozoic rocks which are mainly Devonian and Carboniferous carbonate and sandstone. Previous studies have recorded three stages of granitic magmatic activities in this area: Indosinian (230-220 Ma; [38], early Yanshanian 
(160-150 Ma; [28]) and late Yanshanian (141 Ma; [63]). The Indosinian granites, outcropped as intrusive stock, are mainly coarse-grained porphyritic biotite granites, with K-feldspar ( 40\%), plagioclase $(\sim 25 \%)$, quartz $(\sim 20 \%)$, and biotite $(\sim 15 \%)$ as the main minerals and zircon, apatite, sphene, and magnetite as the accessory minerals [34]. The early Yanshanian granites are mainly composed of fine-grained two mica granites as dykes, with K-feldspar (28-30\%), quartz (28-38\%), plagioclase (25-30\%), and mica (5-12\%, including biotite and muscovite) as the main minerals and magnetite, tourmaline, apatite, topaz and zircon as the accessory minerals [28]. The late Yanshanian granites are exposed rarely, which are mainly muscovite granite [63].

\section{Geology of the Ore Deposits}

Previous studies have revealed that four types of W-Sn polymetallic ore bodies were exploited in the Xitian ore field consisting of skarn-, quartz vein-, greisen- and structurally altered rock-types $[19,60]$. The skarn-type ore bodies, occurred mainly in Longshang, Hejiangkou, and Shaiheling, are characterized by W-Sn mineralization (Figure 2). The quartz vein- and greisen-type ore bodies are also characterized by W-Sn mineralization, distributed in Longshang, Hejiangkou, Heshuxia, and Goudalan (Figure 2). The structurally altered rock-type ore bodies are mainly found in Shaiheling featured by Lead (Pb)-Zinc ( $\mathrm{Zn}$ ) mineralization (Figure 2). The morphology of ore body, specimen and micrographs were presented in Figures 3 and 4, respectively.

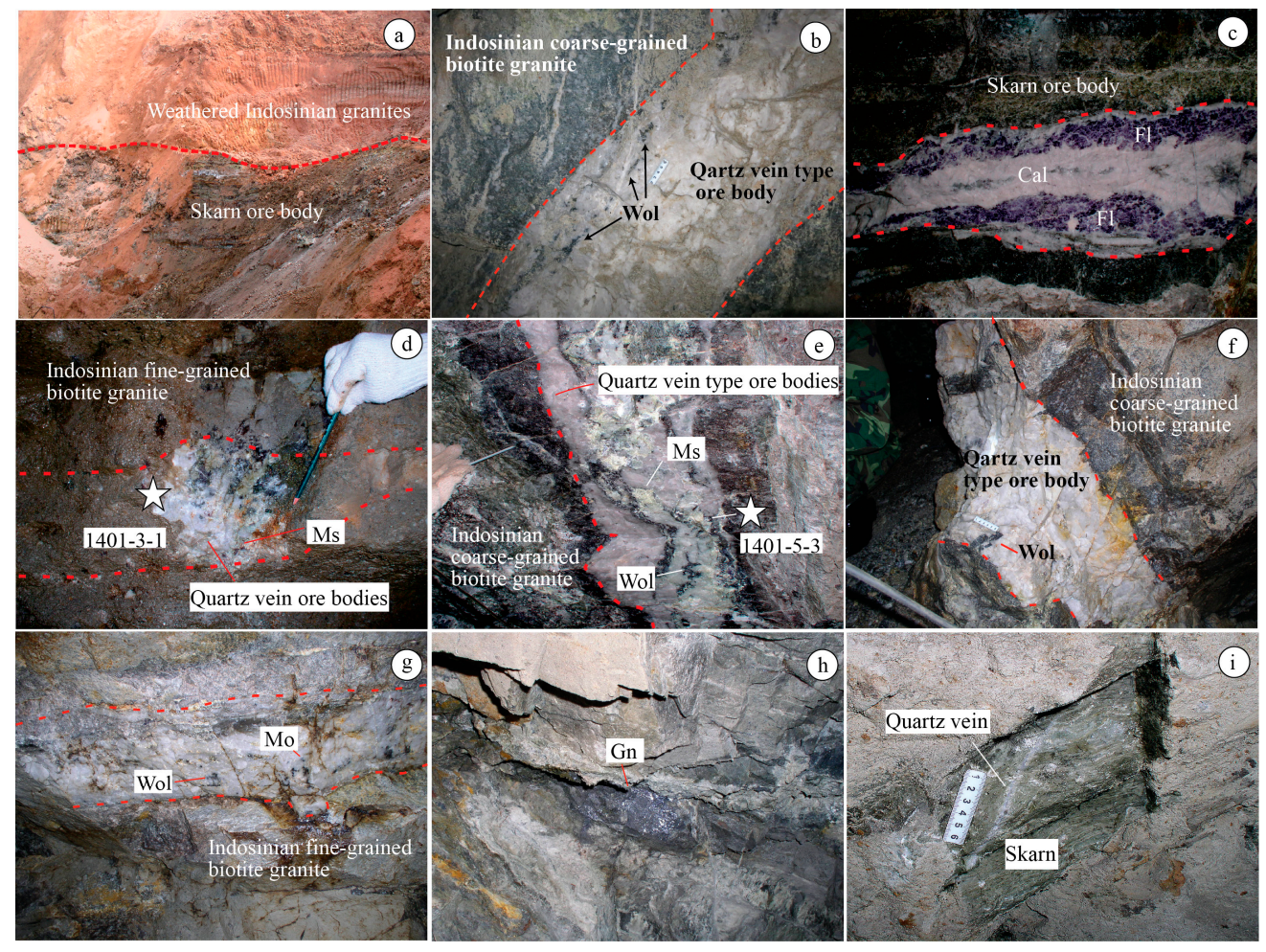

Figure 3. Photographs of the related ore bodies showing the morphology of skarn- and quartz vein-type ore body. (a) The stratiform and stratoid ore bodies occurring in the contact zone between the Indosinian granites and the Devonian dolomitic limestone in Longshang ore district; (b) Quartz vein type of ore body in Longshang ore district; (c) Skarn-type ore bodies are superimposed by calcite- and fluorite-veins in Longshang ore district; (d) Quartz vein type of ore body in Hejiangkou ore district; (e) Quartz vein type of ore body in Heshuxia ore district; (f) Quartz vein type of ore body in Heshuxia ore district; (g) Quartz vein type of ore body in Goudalan ore district; (h) The structurally altered rock-type of $\mathrm{Pb}-\mathrm{Zn}$ ore body in Shaiheling ore district; (i) The stratiform and stratoid ore bodies occurring in the contact zone between the Indosinian granites and the Devonian dolomitic limestone in Shaiheling ore district; Cal: calcite; Fl: fluorite; Gn: galenite; Mo: molybdenite; Ms: muscovite; Wol: wolframite. 

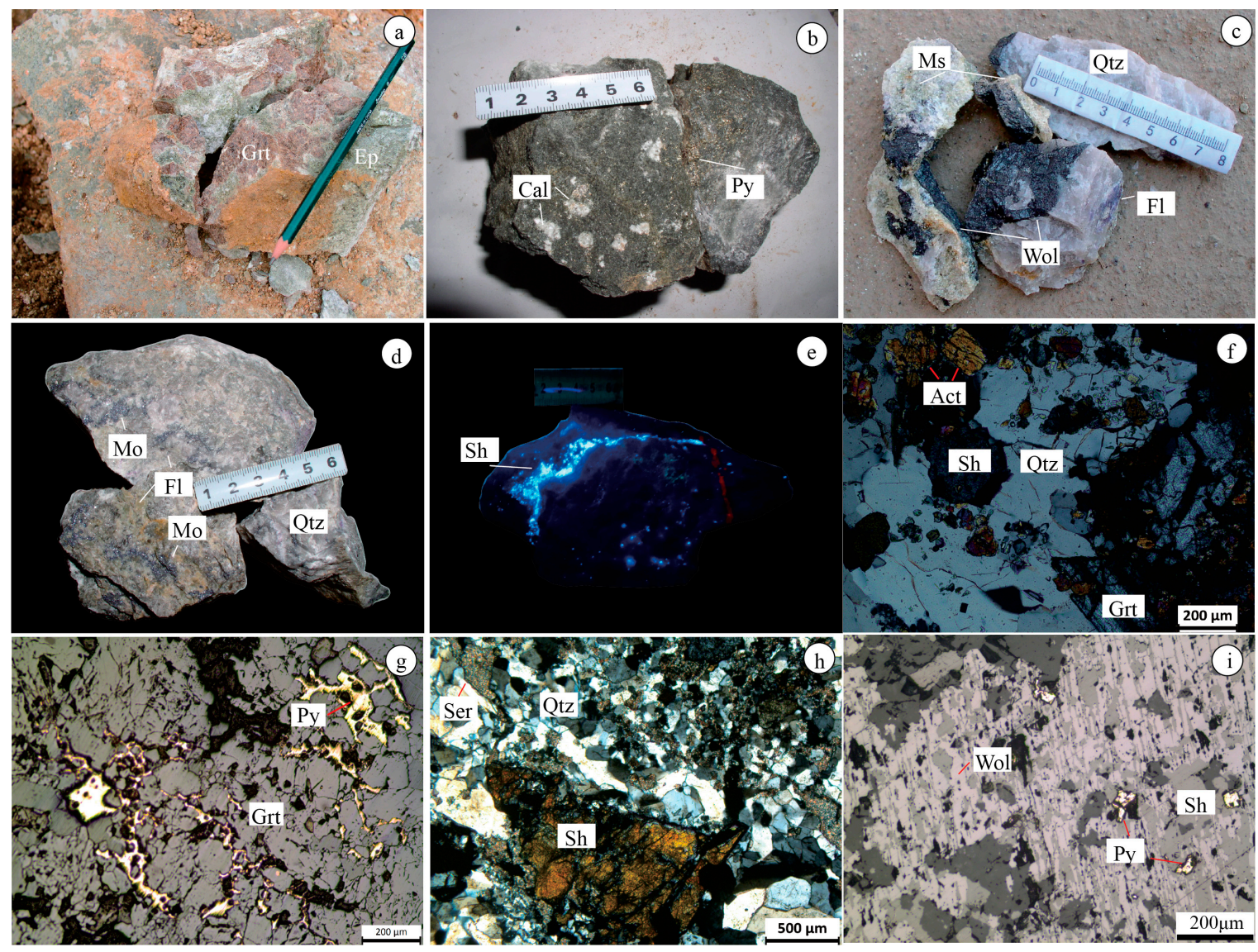

Figure 4. Photographs showing representative mineral assemblages and textural features of the skarnand quartz vein type ore. (a) Hand specimen of the skarn showing the skarn mineral assemblages of garnet and epidote; (b) Hand specimen of the skarn type ore showing mineral assemblages of pyrite and calcite; (c) Wolframite-bearing quartz ore in Heshuxia ore district; (d) Molybdenite-bearing quartz ore in Heshuxia ore district; (e) Scheelite-bearing quartz ore in Heshuxia ore district (under a tungsten lamp); (f) Scheelite coexisting with quartz, garnet, and actinolite; (g) The xenomorphic pyrite coexisting with the garnet; (h) Scheelite with quartz and sericite; (i) Scheelite coexisting with wolframite and pyrite, and replacing the wolframite. Act: actinolite; Cal: calcite; Ep: epidote; Fl: fluorite; Grt: garnet; Py: pyrite; Mo: molybdenite; Ms: muscovite; Qtz: quartz; Ser: sericite; Sh: scheelite; Wol: wolframite.

\subsection{Longshang}

The Longshang deposit, located in the western part of the Xitian ore field, is the largest W-Sn deposit in this area (Figure 2). Two types of ore body are exploited in this deposit, which are skarn- and quartz vein type. The skarn-type W-Sn ore bodies are stratiform, stratoid and lentoid, mainly occurring at the endo- or exo-contact zone between the Xitian Triassic granites and the Devonian dolomitic limestone (Figure 3a). In addition, the N-S-trending and E-dipping skarn-type ore bodies are $2700 \mathrm{~m}$ long and $4.5-33.1 \mathrm{~m}$ thick with ore grade of $0.14-0.77 \% \mathrm{Sn}$ and $0.038-0.83 \% \mathrm{WO}_{3}$ [35]. The quartz vein-type ore bodies, occurring in the Xitian Triassic granites, are E-W-trending and S-dipping with ore veins of 3-20 cm in thickness (Figure $3 b$ ). A complex skarn-vein type W-Sn ore bodies, newly found in the Longshang deposit, have relatively high grade with $2.3 \% \mathrm{WO}_{3}$ and $1.7 \% \mathrm{Sn}$ in some parts of the ore bodies (Figure 3c).

The major ore minerals of skarn-type ore bodies comprise scheelite, pyrite, and some other minerals, with gangue mineral mainly consisting of garnet, epidote, idocrase, quartz, and other skarn minerals (Figure $4 \mathrm{a}, \mathrm{b}, \mathrm{f}, \mathrm{g}$ ). The major ore minerals in quartz vein-type ore bodies are wolframite, 
cassiterite, scheelite, pyrite, and some other minerals, with gangue mineral mainly consisting of quartz, fluorite, calcite, and sericite.

\subsection{Hejiangkou}

The Hejiangkou deposit is also located in the western part of the Xitian ore field (Figure 2). Similar to the Longshang deposit, Hejiangkou is also characterized by skarn-type Sn-Cu mineralization and quartz vein type W-Sn mineralization. The stratiform and lentoid skarn-type ore bodies are the mainly mining target in this deposit, which occur in the endo- or exo-contact zone between the Xitian Triassic granites and the Devonian limestone, with 500-1200 m long and 30-50 m thick. The quartz vein-type W-Sn ore veins, hosted in the Xitian Triassic granites and Devonian sandstone, are NEE and/or NNW-trending and N-dipping with ore veins of 50-200 m long and 0.1-0.8 m thick (Figure 3d).

Ore minerals of the skarn-type ore bodies are mainly cassiterite, chalcopyrite, scheelite, sphalerite, and pyrite, with gangue minerals consisting of quartz, calcite, garnet, epidote, idocrase and other skarn minerals. Ore minerals of the quartz vein-type ore bodies are mainly composed of wolframite, cassiterite, scheelite, and pyrite, and gangue minerals are quartz, fluorite, and muscovite.

\subsection{Heshuxia}

The Heshuxia deposit is in the eastern part of the Xitian ore field (Figure 2). Unlike the Longshang and Hejiangkou deposits in the western part of the Xitian ore field, the Heshuxia deposit is mainly characterized by quartz vein type of $\mathrm{W}$ mineralization. The $\mathrm{NW}$-trending and SW-dipping ore veins are mainly hosted in the Xitian Triassic granites, with length of 100-1000 m, thickness of 30-100 cm, and ore grade of $0.172-0.700 \% \mathrm{WO}_{3}$ (Figure $3 \mathrm{e}, \mathrm{f}$ ). Ore minerals are mainly wolframite, with a small quantity of scheelite, molybdenite, pyrite, and chalcopyrite. Gangue minerals are mainly composed of quartz, fluorite, and muscovite (Figure 4c,d,e,h,i).

\subsection{Goudalan}

The Goudalan deposit, located in the southeast part of the Xitian ore field, is also characterized by quartz vein type of W-Sn mineralization. The NEE trending ore veins are also hosted in the Xitian Triassic granites with length of $100-1000 \mathrm{~m}$, thickness of $0.1-1 \mathrm{~m}$ and ore grade of $0.086-0.762 \% \mathrm{WO}_{3}$ (Figure 3g). Ore minerals mainly consist of wolframite, with a small quantity of scheelite, molybdenite, pyrite, and chalcopyrite. Gangue minerals are mainly composed of quartz, fluorite, and muscovite.

\subsection{Shaiheling}

The Shaheling deposit, located in the northeast part of the Xitian ore field, are characterized by the structurally altered rock-type of $\mathrm{Pb}-\mathrm{Zn}$ mineralization and skarn-type of $\mathrm{W}$-Sn mineralization. The structurally altered rock-type of $\mathrm{Pb}-\mathrm{Zn}$ ore bodies are mainly hosted in the fracture zone of the skarn and/or carbonate formations, with NW trending and NE dipping (Figure 3h). The skarn-type W-Sn ore bodies are stratiform, stratoid and lentoid, mainly occurring at the endo- or exo-contact zone between the Xitian Triassic granites and the Devonian dolomitic limestone as in the Longshang and Hejiangkou deposits, with average length of $1.4 \mathrm{~km}$ and thickness of $3.3 \mathrm{~m}$ (Figure $3 \mathrm{i}$ ). The ore minerals of the structurally altered rock-type ore mainly comprise of sphalerite, galenite, scheelite, pyrite and chalcopyrite, with gangue minerals consisting of quartz, feldspar, chlorite, and so on. Ore minerals of the skarn-type W-Sn ore are mainly composed of scheelite, cassiterite, pyrite and chalcopyrite, with gangue minerals consisting of quartz, garnet, epidote, and so on.

\section{Sampling and Analytical Methods}

The analyzed samples were collected from underground mines (Figure 2). Zircon grains used for LA-ICP-MS U-Pb dating were separated from a sericitic coarse-grained biotite granite (sample No. 19-4s1, Figure 5a,b) and a sericitic fine-grained two mica granite (sample No. 24-15s1, Figure 5c,d), 
which were collected from the Longshang deposit. The muscovite used for Ar-Ar dating were extracted from quartz vein-type ore in Hejiangkou (Figure 3d, sample 1401-3-1) and Heshuxia (Figure 3e, sample 1401-5-3). The skarn used for geochemical analyses were all endo-skarn, some of which contained sulfides, collected from the Longshang, Shaiheling and Huamu deposits. The wolframite, separated from the quartz vein type ore and used for $\mathrm{Sr}-\mathrm{Nd}-\mathrm{Pb}$ analysis, were collected from Longshang, Goudalan and Heshuxia. The sampling locations were marked in Figure 2.

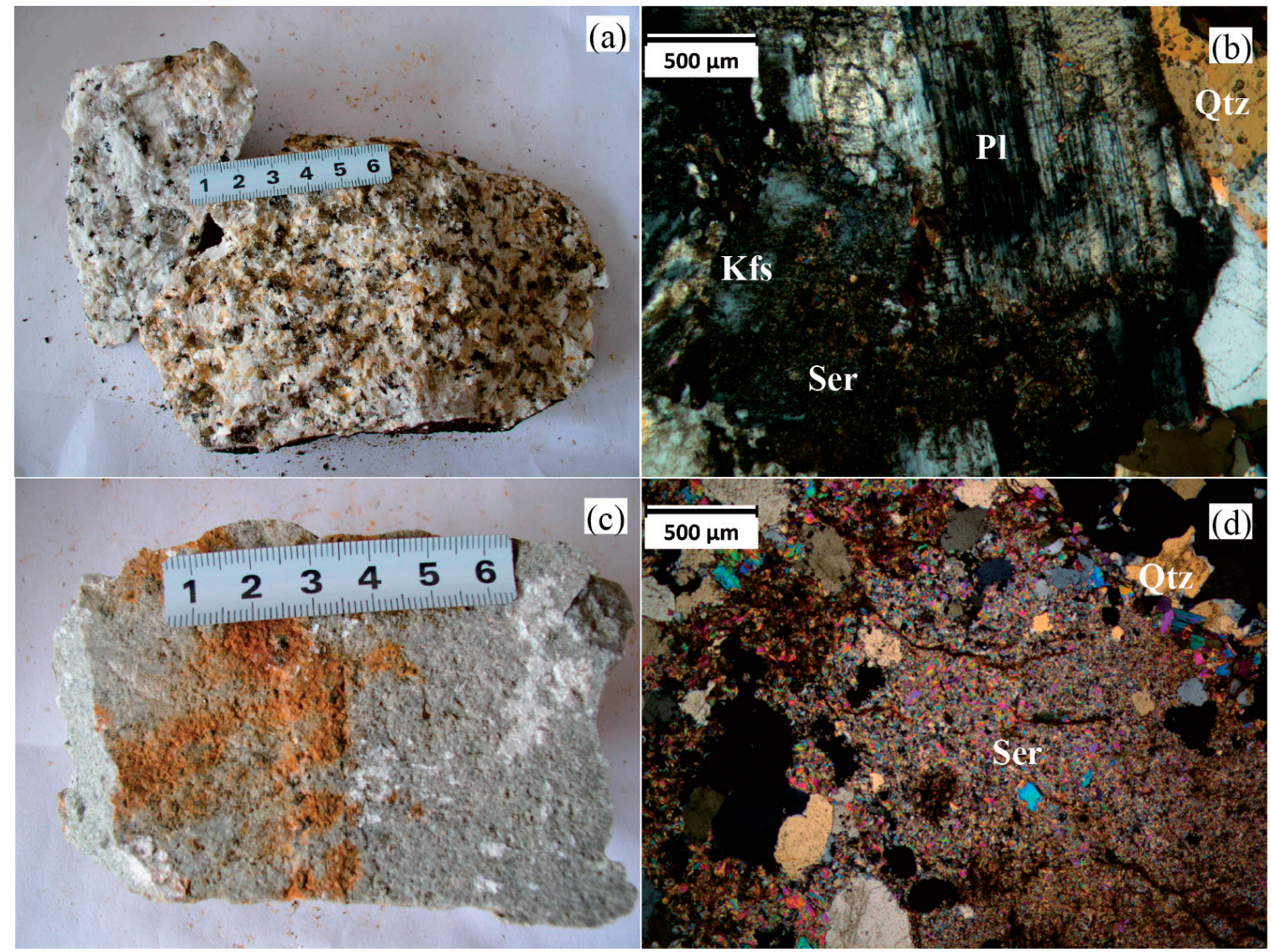

Figure 5. Hand specimen and micrographs of the altered granite. (a) Hand specimen of the altered Indosinian coarse-grained biotite granite; (b) The K-feldspar is altered and replaced by sericite; (c) Hand specimen of the altered Yanshanian fine-grained two-mica granite; (d) Almost the feldspars are altered and replaced by sericite. Kfs: K-feldspar; Pl: plagioclase; Ser: sericite.

\subsection{In Situ LA-ICP-MS Zircon U-Pb Dating and Trace Element Compositions}

Zircon grains from these samples were separated by conventional magnetic and heavy liquid techniques before they were hand-picked under a binocular microscope. They were then mounted into epoxy resin blocks and polished to obtain flat surfaces. Cathodoluminescence (CL) imaging technique was used to visualize the internal structures of individual zircon grains, with a scanning electron microscope (TESCAN MIRA 3 LMH FE-SEM, TESCAN, Brno, Czech Republic) at the Sample Solution Analytical Technology Co., Ltd., Wuhan, China. Zircon U-Pb dating was undertaken with an Agilent 7700 inductively coupled plasma-mass spectrometer (ICP-MS, Agilent, Santa Clara, CA, USA), combined with a Coherent 193 laser ablation (LA) system at Sample Solution Analytical Technology Co., Ltd., Wuhan, China. Two zircon standards, 91500 (1062 \pm 4 Ma; [64] and GJ-1 (610.0 \pm 1.7 Ma; [65], were used as external standards for dating. Standard silicate glass (NIST SRM610) was used for external standardization for trace element analysis, and ${ }^{29} \mathrm{Si}$ was used for internal standardization $\left(32.8 \% \mathrm{SiO}_{2}\right.$ in zircon). The standard protocol correction method was used in analyzing the 91500 and 
GJ-1 standard zircons twice and once, respectively, after every five analyses. The raw ICP-MS data were processed using ICPMSDataCal software [66], and common $\mathrm{Pb}$ was corrected following [67]. Concordia diagrams and weighted mean calculations were processed using Isoplot (version 3.0; [68]).

\subsection{Muscovite ${ }^{40} \mathrm{Ar}^{-39}$ Ar Dating}

The Muscovite grains were carefully handpicked using a binocular microscope from the crushed sample to ensure purity up to $99.9 \%$, then these grains were washed repeatedly in an ultrasonic bath using deionized water and acetone. Aliquots of approximately $10 \mathrm{mg}$ were wrapped in Al foil and stacked in quartz vials. After samples had been stacked, the sealed quartz vials were put in a quartz canister, which was wrapped with cadmium foil ( $0.5 \mathrm{~mm}$ in thickness) to act as a slow neutron shield thereby preventing interface reactions during irradiation. The irradiation procedure was put the samples in channel B4 of Beijing 49-2 reactor for $50 \mathrm{~h}$ at the Chinese Academy of Nuclear Energy Sciences. During irradiation, the vials were rotated at a speed of two cycles per minute to ensure uniformity of the irradiation. The biotite standard ZBH-2506 (132.5 Ma; [69]) was used to monitor the neutron flux. ${ }^{40} \mathrm{Ar} /{ }^{39} \mathrm{Ar}$ stepwise heating analyses were performed at the Key Laboratory of Tectonics and Petroleum Resources, China University of Geosciences, Wuhan, China. Analyses were carried out using an Argus VI mass spectrometer combined with Coherent $50 \mathrm{~W} \mathrm{CO}_{2}$ laser system. The time of heating was $60 \mathrm{~s}$ for every single stage with a laser beam diameter of $2.5 \mathrm{~mm}$, and the time of gas purification was $400 \mathrm{~s}$ with two $\mathrm{Zr}-\mathrm{Al}$ scavenger. The detailed analytical procedures were given by [70]. $\mathrm{K}_{2} \mathrm{SO}_{4}$ and $\mathrm{CaF}_{2}$ crystals were analyzed to calculate $\mathrm{Ca}, \mathrm{K}$ correction factors: $\left({ }^{39} \mathrm{Ar} /{ }^{37} \mathrm{Ar}\right)_{\mathrm{Ca}}=$ $8.984 \times 10^{-4},\left({ }^{36} \mathrm{Ar} /{ }^{37} \mathrm{Ar}\right)_{\mathrm{Ca}}=2.673 \times 10^{-4},\left({ }^{40} \mathrm{Ar} /{ }^{39} \mathrm{Ar}\right)_{\mathrm{K}}=5.97 \times 10^{-3}$. The data-processing software and diagrams of plateau age we used was the ArArCALC 2.52 software by [71].

\subsection{Skarn Major and Trace Elements Analysis}

The skarn samples were crushed in a milling machine to 200 mesh before elemental analyses were conducted. The major and trace element compositions of skarn were analyzed at ALS Chemex, Guangzhou, China. The major element contents were measured using a Panalytical Axios Max X-ray fluorescence (XRF, Panalytical, Almelo, The Netherlands) instrument, with analytical accuracy of about 1-5\%. Trace element compositions were measured using ICP-MS (Perkin Elmer Elan 9000, Perkin, Waltham, MA, USA), with analytical accuracy of better than $5 \%$.

\subsection{Wolframite $\mathrm{Sr}-\mathrm{Nd}-\mathrm{Pb}$ Isotopic Composition Analysis}

$\mathrm{Sr}-\mathrm{Nd}-\mathrm{Pb}$ isotopic analyses were carried out at the Key Laboratory of Crust-Mantle Materials and Environments, Chinese Academy of Sciences, University of Science and Technology of China, Hefei, China, using a Finnigan MAT-262 multicollector thermal ionization mass spectrometer (MC-TIMS). $\mathrm{Rb}$-Sr was separated and purified using conventional cation exchange (AG50W-X12, 200-400 resin), whereas Sm and Nd were separated and purified using Teflon and a Power resin, respectively. The correction for mass fractionation of the Sr-Nd isotopic ratio was undertaken by normalizing to ${ }^{86} \mathrm{Sr} /{ }^{88} \mathrm{Sr}$ $=0.1194$ and ${ }^{146} \mathrm{Nd} /{ }^{144} \mathrm{Nd}=0.7219$. The Sr standard $\left(\mathrm{NBS} 987,{ }^{87} \mathrm{Sr} /{ }^{86} \mathrm{Sr}=0.710249 \pm 0.000012(2 \sigma)\right)$ and the $\mathrm{Nd}$ standard (La Jolla, ${ }^{143} \mathrm{Nd} /{ }^{144} \mathrm{Nd}=0.511869 \pm 0.000006(2 \sigma)$ ) were used as the standard solution in this study. The analytical accuracy of the $\mathrm{Sr}$ and $\mathrm{Nd}$ isotope data are superior to $0.003 \%$. The ${ }^{208} \mathrm{~Pb} /{ }^{206} \mathrm{~Pb},{ }^{207} \mathrm{~Pb} /{ }^{206} \mathrm{~Pb}$, and ${ }^{204} \mathrm{~Pb} /{ }^{206} \mathrm{~Pb}$ ratios of the $\mathrm{Pb}$ standard (NBS981) are $2.1681 \pm 0.0008(2 \sigma)$, $0.91464 \pm 0.00033(2 \sigma)$, and $0.059042 \pm 0.000037(2 \sigma)$, respectively. The analytical accuracy of the $\mathrm{Pb}$ isotope data is better than $0.01 \%$. Specific procedures of the $\mathrm{Sr}-\mathrm{Nd}-\mathrm{Pb}$ isotopic analytical techniques are given by [72]. 


\section{Results}

\subsection{Zircon U-Pb Dating}

Most of zircon grains of sample 19-4s1 are euhedral or subhedral in shape and black in CL imaging. The length of zircons ranges from 80 to $180 \mu \mathrm{m}$ with length-to-width ratios from 1:1 to 3:1. CL images show that these zircons are with weak internal oscillatory zoning, and/or irregular, patchy to granular internal structures, and growth zonings can be found in some zircons (zircon No. 8, 9, 12, and 15, Figure 6a), indicating that they might not be the typical magmatic zircons [73]. Th and U contents of these zircon grains vary from 509 ppm to 1495 ppm (mean = 931 ppm) and 663 ppm to 3129 ppm $($ mean $=1705 \mathrm{ppm})$, respectively. The Th/U ratios are variable ranging from 0.18 to $1.73(\mathrm{mean}=0.66)$. Several isotopic data of the analyzed zircon grains have relatively big errors, which are eliminated in the process of dating calculation. The ${ }^{206} \mathrm{~Pb} /{ }^{238} \mathrm{U}$ ages of thirteen zircons ranges from $216.4 \mathrm{Ma}$ to 233.5 Ma which plot on or near the concordia curve (Table S1 of Supplementary Materials), yielding a weighted mean ${ }^{206} \mathrm{~Pb} /{ }^{238} \mathrm{U}$ age of $226.0 \pm 2.8 \mathrm{Ma}(\mathrm{MSWD}=2.1$, Figure $6 \mathrm{~b}$ ).
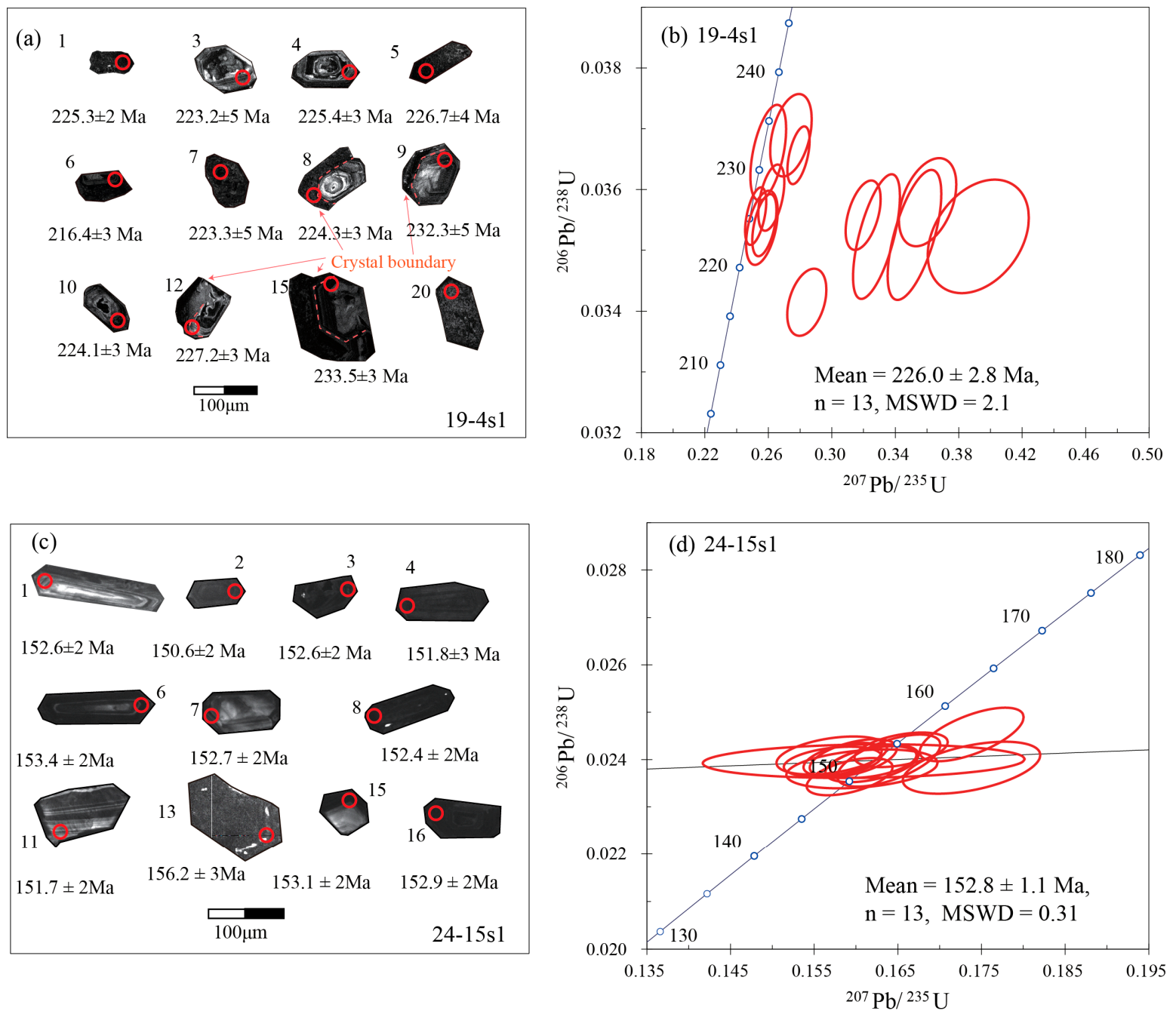

Figure 6. Cathodoluminescence (CL) images of representative zircon grains and concordia diagrams of zircon U-Pb geochronological data for the samples taken from the Xitian ore field. (a) Cathodoluminescence (CL) images of the zircons from altered Indosinian granites; (b) Concordia diagram of zircon $\mathrm{U}-\mathrm{Pb}$ data for the altered Indosinian granites; (c) Cathodoluminescence (CL) images of the zircons from altered Yanshanian granites; (d) Concordia diagram of zircon U-Pb data for the altered Yanshanian granites. 
Most of the zircon grains from sample 24-15s1 are xenotopic, with small amounts of idiomorph, and the aspect ratios are ranging from 1:1 to 4:1 with lengths of 50-200 $\mu \mathrm{m}$. CL imaging indicates that most of the zircon grains are black in color with weak internal oscillatory zoning, and/or granular internal texture (Figure 6c). These grains show abnormally high contents of $U$ (3277-59,113 ppm; mean $=30,823 \mathrm{ppm})$, and Th (3347-14,922 ppm; mean = 6389 ppm, Table S1 of Supplementary Materials), which is much higher than the granites without alteration in Xitian pluton with $U$ (354-7047 ppm) and Th (192-1257 ppm) contents [28]. Their relatively low Th/U ratios $(0.209-0.67$, mean $=0.25)$ indicate a hydrothermal origin [73]. The ${ }^{206} \mathrm{~Pb} /{ }^{238} \mathrm{U}$ ages of 13 zircon grains from this sample range from 150.6 Ma to 156.2 Ma (Table S1 of Supplementary Materials) and are plotted on or close to the concordia curve, with a weighted mean ${ }^{206} \mathrm{~Pb} /{ }^{238} \mathrm{U}$ age of $152.8 \pm 1.1 \mathrm{Ma}$ (MSWD $=0.31$; Figure $6 \mathrm{~d}$ ).

\subsection{Trace Element Compositions of Zircons}

The zircon grains used for trace element analysis are the same as those which were dated in this study. Their trace element compositions and related parameters are given in Table S2 of Supplementary Materials.

Zircon grains of sample 19-4s1 are characterized by high contents of the heavy rare earth elements (HREEs) and relatively low contents of light rare earth elements (LREEs), with LREE/HREE ratios ranging from 0.04 to 0.24 (mean $=0.1$ ). They also have relatively variable and high contents of the rare earth elements (REEs) with $\Sigma$ REE ranging from $623 \mathrm{ppm}$ to $2058 \mathrm{ppm}$ (mean $=1071 \mathrm{ppm}$ ). Chondrite normalized REE patterns of these zircon grains are characterized by steep slopes, elevated heavy rare earth elements (HREEs), positive Ce anomalies (most of the Ce/Ce* ratios range from 1.61 to 74.14, with average $=10.84)$, and negative Eu anomalies $\left(\mathrm{Eu} / \mathrm{Eu}^{*}=0.17-0.41\right.$, mean $=0.28$, Figure $\left.7 \mathrm{a}\right)$.
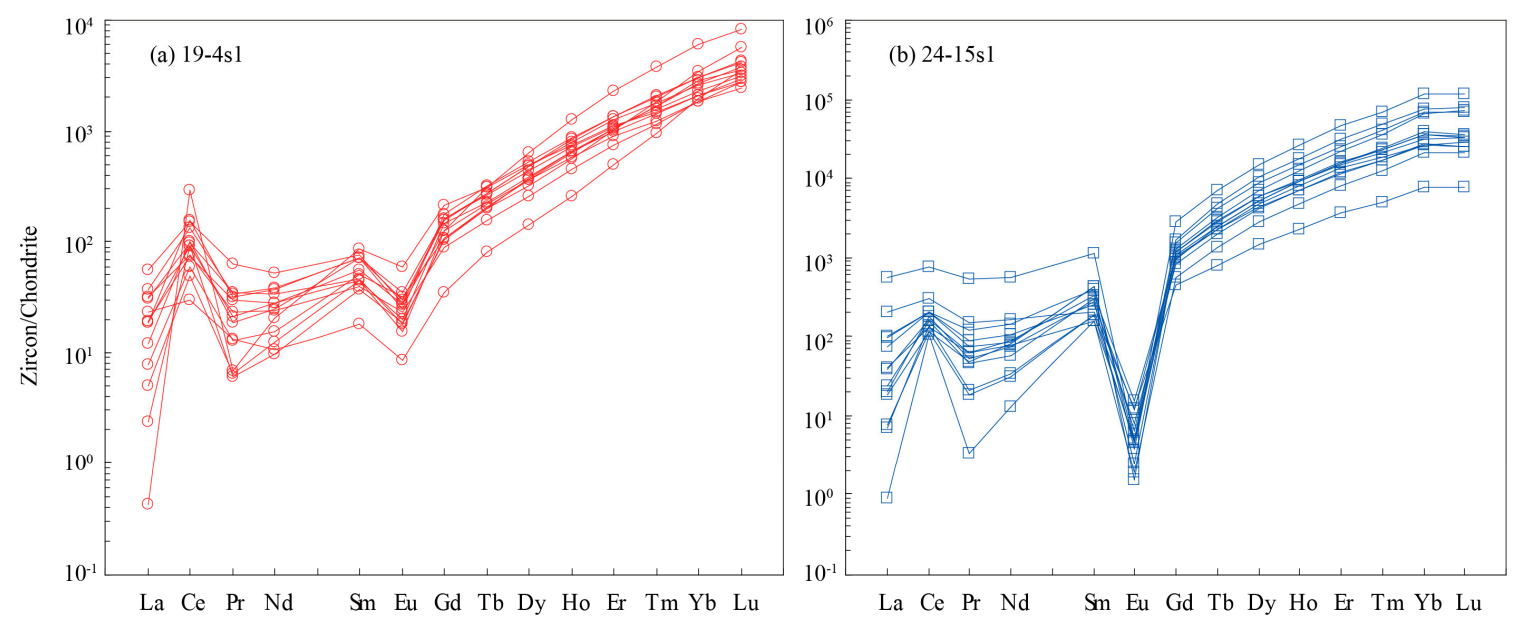

Figure 7. Chondrite-normalized REE chemistry of zircon grains for the samples taken from the Xitian ore field, with normalizing factors from [74]. (a) Chondrite-normalized REE chemistry of zircon grains for altered Indosinian granites; (b) Chondrite-normalized REE chemistry of zircon grains for altered Yanshanian granites.

Zircon grains from sample 24-15s1 are also characterized by high contents of the heavy rare earth elements (HREEs) and relatively low contents of light rare earth elements (LREEs), with LREE/HREE ratios ranging from 0.01 to 0.13 (mean $=0.02$ ). The REEs contents are tremendously high with $\Sigma$ REE ranging from $7073 \mathrm{ppm}$ to 39,062 ppm (mean $=15,241 \mathrm{ppm}$ ) and $\mathrm{Y}$ ranging from $3995 \mathrm{ppm}$ to 43,198 ppm (mean $=18,180 \mathrm{ppm}$ ). Chondrite normalized REE patterns that are also characterized by steep slopes, elevated heavy rare earth elements (HREEs), relatively positive Ce anomalies (most of the $\mathrm{Ce} / \mathrm{Ce}^{*}$ ratios range from $=1.33-8.88$, mean $=3.68$ ), and significant negative Eu anomalies $\left(\mathrm{Eu} / \mathrm{Eu}^{*}=0.01-0.04\right.$, mean $=0.01$, Figure $\left.7 \mathrm{~b}\right)$. 
In addition, both of these zircon grains of two samples have relatively high contents of La, low ratios of $(\mathrm{Sm} / \mathrm{La})_{\mathrm{N}}$ and $\mathrm{Ce} / \mathrm{Ce}^{*}$, and most of the zircon grains are plotted in the hydrothermal field in the diagram of $\mathrm{La}$ versus $(\mathrm{Sm} / \mathrm{La})_{\mathrm{N}}$ and $(\mathrm{Sm} / \mathrm{La})_{\mathrm{N}}$ versus $\mathrm{Ce} / \mathrm{Ce}^{*}$, indicating a hydrothermal origin of these samples (Figure 8a,b; [75]).
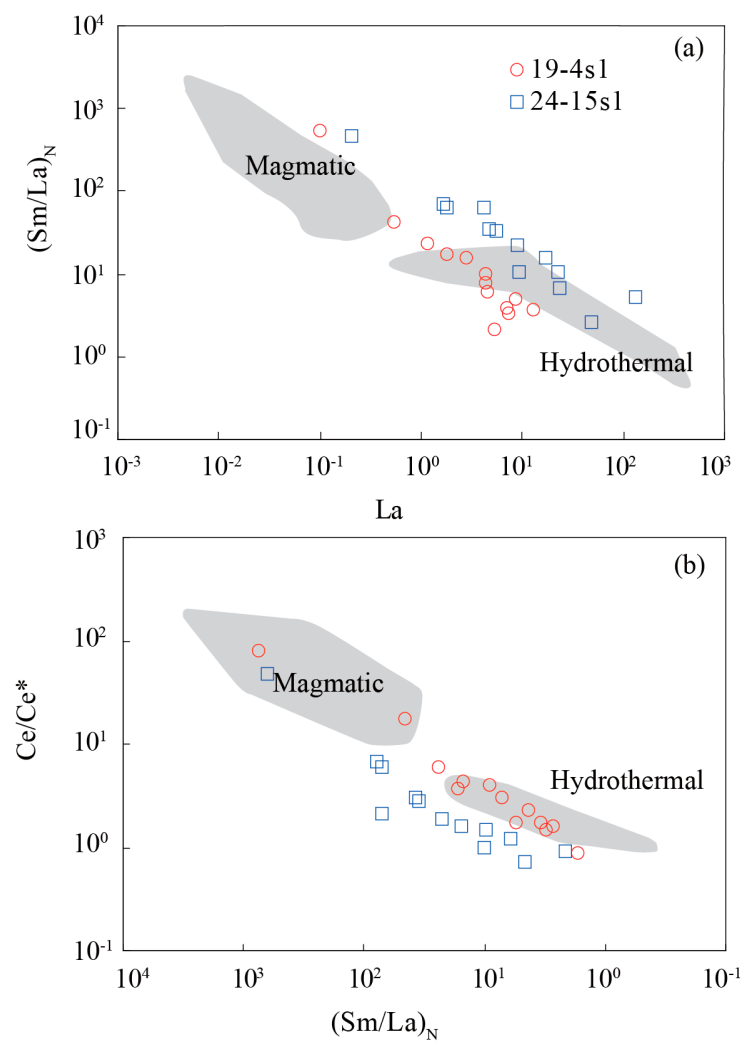

Figure 8. (a) La versus $(\mathrm{Sm} / \mathrm{La})_{\mathrm{N}}$; and $(\mathbf{b})(\mathrm{Sm} / \mathrm{La})_{\mathrm{N}}$ versus Ce/Ce* plots of samples from the Xitian ore field, modified from [75].

\subsection{Muscovite ${ }^{40}$ Ar- ${ }^{39}$ Ar Dating}

The Ar-Ar isotopic data of two muscovite samples are given in Table S3 of Supplementary Materials. Thirteen laser-heating stages were carried out for sample 1401-3-1, and stages from 6 to 12 had been obtained the flat age spectrum. This sample yields a plateau age of $156.6 \pm 0.7 \mathrm{Ma}$ (MSWD $=0.51$, Figure 9a) with $60 \%$ release of ${ }^{39} \mathrm{Ar}$, consistent with the inverse isochron age of $156.0 \pm 0.7 \mathrm{Ma}(\mathrm{MSWD}=0.50$, Figure $9 \mathrm{~b}$ ).

Seventeen laser-heating stages were carried out for sample 1401-5-3, and stages from 4 to 16 had been obtained the flat age spectrum. This sample yields a well-defined plateau age of $150.0 \pm 0.6 \mathrm{Ma}$ (MSWD $=0.39 \mathrm{Ma}$, Figure 9c) with $97 \%$ release of ${ }^{39} \mathrm{Ar}$, consistent with the inverse isochron age of $149.5 \pm 0.8 \mathrm{Ma}(\mathrm{MSWD}=0.17$, Figure 9d). 

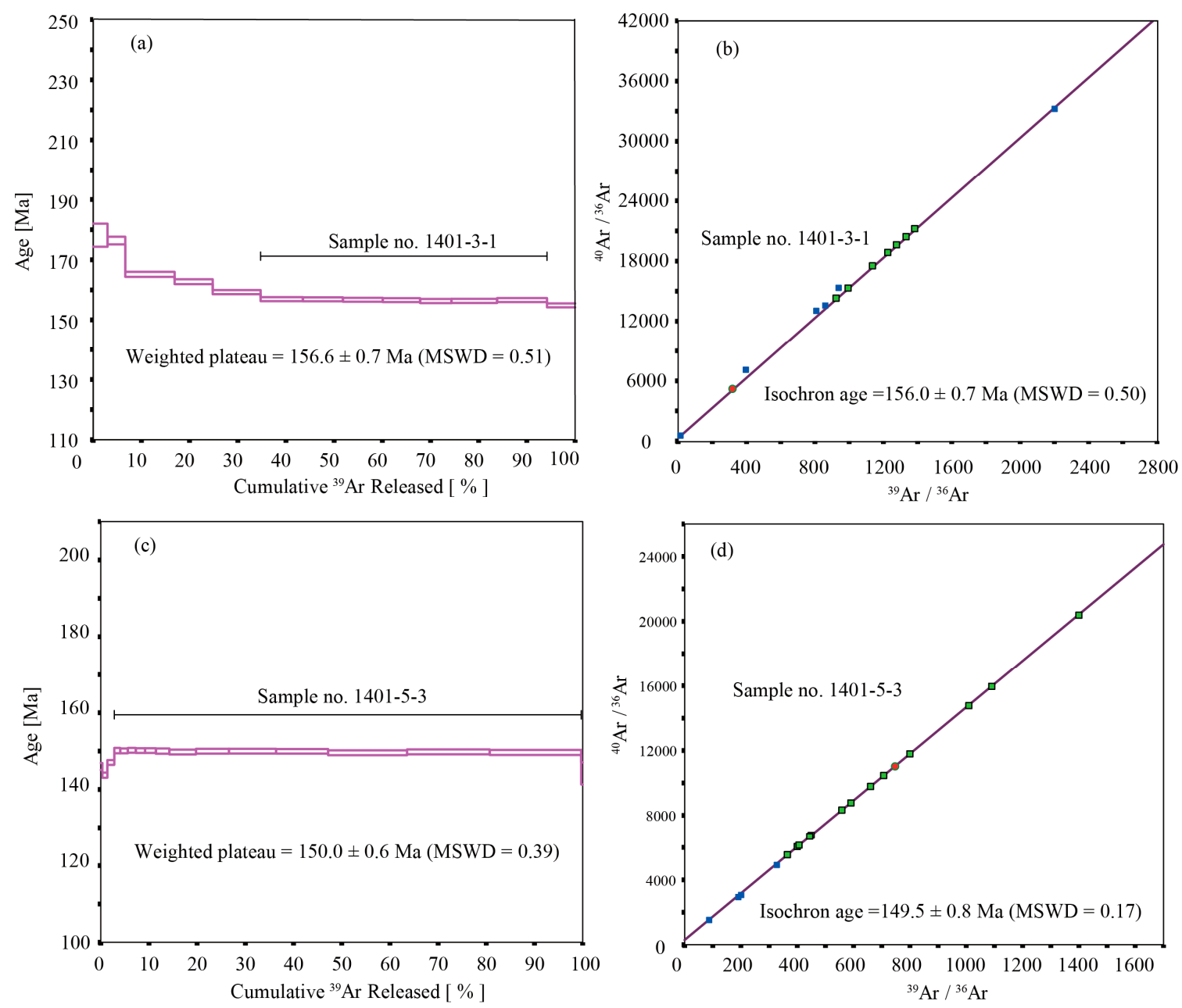

Figure 9. ${ }^{39} \mathrm{Ar}-{ }^{40} \mathrm{Ar}$ age spectra and isochron for muscovite samples from the Xitian ore field. (a) Diagram of the plateau age for the 1401-3-1 muscovite; (b) Diagram of isochron age for the 1401-3-1 muscovite; (c) Diagram of the plateau age for the 1401-5-3 muscovite; (d) Diagram of isochron age for the 1401-5-3 muscovite.

\subsection{Skarn Major and Trace Elements Analysis Results}

The representative bulk chemical compositions (major elements) of skarns in the Xitian ore field are presented in Table S4 of Supplementary Materials. These samples have relatively wide ranges of chemical compositions, with $\mathrm{SiO}_{2}=30.1-51.2 \%, \mathrm{TiO}_{2}=0.07-0.56 \%, \mathrm{Al}_{2} \mathrm{O}_{3}=2.33-12.50 \%, \mathrm{TFe}_{2} \mathrm{O}_{3}=2.12-23.96 \%$, $\mathrm{MnO}=0.07-0.82 \%, \mathrm{MgO}=1.86-12.85 \%, \mathrm{CaO}=14.80-34.8 \%, \mathrm{Na}_{2} \mathrm{O}=0.03-0.28 \%, \mathrm{~K}_{2} \mathrm{O}=0.04-4.68 \%$, and $\mathrm{SO}_{3}=0.03-10.20 \%$.

The trace and rare earth elements (REEs) contents of skarns are given in Table S4 of Supplementary Materials. The total REE ( $\Sigma$ REE) contents range from 40.4 to $184.5 \mathrm{ppm}$ (mean $=103.2 \mathrm{ppm}$ ), with high $(\mathrm{La} / \mathrm{Yb})_{\mathrm{N}}$ ratios (5.2-13.2), and significant negative Eu anomalies $\left(\mathrm{Eu} / \mathrm{Eu}^{*}=0.36-0.82\right)$. The REE distribution patterns display right-dipping V-type curves, which are exactly similar to those of the Indosinian granites in Xitian (Figure 10a). These samples also show similar primitive-mantle-normalized trace element patterns to those of Indosinian granites in Xitian, characterized by enrichment in $\mathrm{Rb}, \mathrm{K}, \mathrm{U}, \mathrm{Zr}, \mathrm{Hf}$ and $\mathrm{REE}$, and depletion in $\mathrm{Ti}, \mathrm{P}, \mathrm{Sr}, \mathrm{Ba}$, and $\mathrm{Nb}$, which are also similar to the Indosinian granites in the Xitian ore field (Figure 10b). 

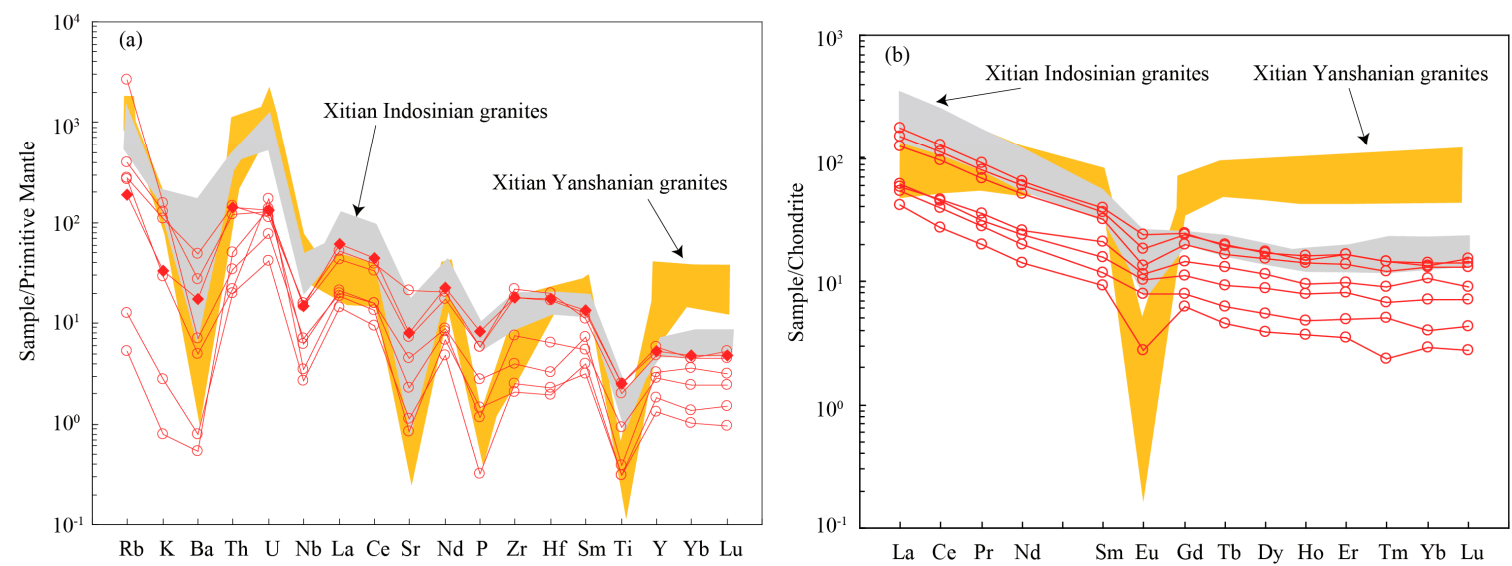

Figure 10. (a) Chondrite-normalized REE chemistry; and (b) primitive-mantle-normalized incompatible trace element variation diagram for the skarn samples taken from the Xitian ore field. Normalizing factors are from [76]. Data for the Xitian Indosinian and Yanshanian granites are from [28,38].

\subsection{Wolframite $\mathrm{Sr}-\mathrm{Nd}-\mathrm{Pb}$ Isotopic Composition Analysis}

The wolframite Sr-Nd isotopic compositions of the four samples analyzed in this study are given in Table S5 of Supplementary Materials. The initial ${ }^{87} \mathrm{Sr} /{ }^{86} \mathrm{Sr}$ and ${ }^{143} \mathrm{Nd} /{ }^{144} \mathrm{Nd}$ ratios were calculated using the muscovite ${ }^{40} \mathrm{Ar}^{-39} \mathrm{Ar}$ dating result of $150.0 \pm 0.6 \mathrm{Ma}$. These samples have high initial $\left({ }^{87} \mathrm{Sr} /{ }^{86} \mathrm{Sr}\right)_{\mathrm{i}}$ ratios $(0.71282-0.72003)$, low initial $\left({ }^{143} \mathrm{Nd} /{ }^{144} \mathrm{Nd}\right)_{\mathrm{i}}$ ratios $(0.511644-0.512155)$, negative $\varepsilon_{\mathrm{Nd}}(\mathrm{t})$ values ranging from -15.6 to -5.6 , and old model ages $\left(\mathrm{T}_{\mathrm{DM} 2}\right)$ of $2168-1396 \mathrm{Ma}$.

$\mathrm{The} \mathrm{Pb}$ isotopic compositions of the samples are shown in Table S5 of Supplementary Materials. All samples are enriched in radiogenic $\mathrm{Pb}$, with ${ }^{206} \mathrm{~Pb} /{ }^{204} \mathrm{~Pb}$ ratios of $18.489-18.569,{ }^{207} \mathrm{~Pb} /{ }^{204} \mathrm{~Pb}$ ratios of 15.724-15.877, and ${ }^{208} \mathrm{~Pb} /{ }^{204} \mathrm{~Pb}$ ratios of 39.055-39.335, respectively. The $\mathrm{Pb}$ isotopic values were calculated with the muscovite ${ }^{40} \mathrm{Ar}-{ }^{39} \mathrm{Ar}$ dating result of $150.0 \pm 0.6 \mathrm{Ma}$ using single-stage $\mathrm{Pb}$ isotopic evolution model [77], with values of $\Delta \beta$ ranging from 26.09 to $36.06, \Delta \gamma$ values from 48.95 to 58.62 , and $\mu$ values from 9.81 to 9.99 , respectively.

\section{Discussion}

\subsection{Timing of Mineralization and Granitic Magmatism}

In order to constrain the time interval of mineralization in the Xitian W-Sn deposit, several studies have been carried out using various dating technologies [19,40-42,78]. It was first reported the muscovite ${ }^{40} \mathrm{Ar}^{39}{ }^{39} \mathrm{Ar}$ isotopic ages of ore-bearing quartz vein in skarn and greisen in the Longshang deposit, with ages of $155.6 \pm 1.3 \mathrm{Ma}$ and 157.2 $\pm 1.4 \mathrm{Ma}$, respectively [41]. Then, some authors obtained the metallogenic age of other deposits in the Xitian ore field, such as Heshuxia (molybdenite Re-Os age of $150.0 \pm 2.7 \mathrm{Ma}$; [78]), Shantian (molybdenite Re-Os age of $158.9 \pm 2.2 \mathrm{Ma}$; [40]), and Hejiangkou (molybdenite Re-Os age of $225.5 \pm 3.6 \mathrm{Ma}$; [43]). An overwhelming majority of dating minerals are collected from ore-bearing quartz vein and/or greisen with ages ranging from $159 \mathrm{Ma}$ to $149 \mathrm{Ma}$ which has a congruent relationship with the early Yanshanian granitic magmatism $[19,40-42,78]$. It seems that the quartz vein and/or greisen type ore bodies in the Xitian W-Sn deposit is close to the early Yanshanian magmatic hydrothermal activities. It was reported a molybdenite Re-Os age of $225.5 \pm 3.6 \mathrm{Ma}$ of altered granite in the Hejiangkou deposit, regarded as the proof for the Indosinian mineralization in Xitian ore field [43]. Here, we reported a muscovite ${ }^{40} \mathrm{Ar}^{-39} \mathrm{Ar}$ isotopic age of the quartz vein type ore body $(156.0 \pm 0.7 \mathrm{Ma})$ in the Hejinagkou deposit of the Xitian ore field, indicating that the quartz vein type W-Sn mineralization in this deposit is closely linked to Yanshanian granitic magmatic activities. However, there is still no direct chronologic evidence to seek an answer for the skarn-type mineralization and restricting the genesis of the skarn-type mineralization 
in this area. We reported the muscovite ${ }^{40} \mathrm{Ar}^{39} \mathrm{Ar}$ isotopic ages of ore-bearing quartz vein for the Hejiangkou deposit and Heshuxia deposit, and two hydrothermal zircon U-Pb ages for the altered granites are $156.6 \pm 0.7 \mathrm{Ma}, 149.5 \pm 0.8 \mathrm{Ma}, 152.8 \pm 1.1 \mathrm{Ma}$, and $226.0 \pm 2.8 \mathrm{Ma}$, respectively. Together with the ages published and obtained in this study, we draw a conclusion that there two phases of metallogenic events have been recorded with the time interval of the quartz vein and greisen type W-Sn mineralization ranging from 159 to $149 \mathrm{Ma}$ and skarn-type W-Sn mineralization ca. $225 \mathrm{Ma}$ in the Xitian ore field, respectively.

The Yanshanian period is a significant time interval of granitic magmatism and W-Sn metallogenesis in the Nanling region, which was regarded as the period of mineralization explosion in South China [79]. However, compared with the Yanshanian W-Sn mineralization event in the Nanling region, the Indosinian W-Sn mineralization event is inconspicuous (Table S6 of Supplementary Materials). Although only a few deposits were determined to be the products of Indosinian magmatic hydrothermal events, such as Shuiyuanshan (220.6 $\pm 1.1 \mathrm{Ma}$; [31]), Yeziwo (227.2 \pm 1.5 ; [31]), Hehuaping (224.0 $\pm 1.9 \mathrm{Ma}$; [32]), and Limu (214.1 $\pm 1.9 \mathrm{Ma}$; [33]), it indicates that the Indosinian is also an important epoch for the W-Sn mineralization in South China.

\subsection{Physico-Chemical Conditions of the Ore-Forming Fluids}

Recently, several studies proved that chemical compositions of zircons could be used as a valid tracer to reflect the physico-chemical conditions of the magmatic melt and/or hydrothermal fluid [80-84]. Specifically, the positive Ce anomalies in zircon are the result of the oxidation of $\mathrm{Ce}^{3+}$ to $\mathrm{Ce}^{4+} . \mathrm{Ce}^{4+}$ is compatible in zircon and can substitute for $\mathrm{Zr}^{4+}, \mathrm{Hf}^{4+}$ and other tetravalent elements in zircon lattice. Thus, $\mathrm{Ce}$ anomalies can provide information for the oxidation state of magma and/or related fluid, where higher $\mathrm{Ce} / \mathrm{Ce}^{*}$ ratios are in accordance with the high oxygen fugacity $\left(f \mathrm{O}_{2} ;[83-85]\right.$. However, zircon $\mathrm{Eu}$ anomalies are not the efficient tracer, because Eu anomalies in zircon are controlled not only by the redox state of the fluids but also by the crystallization history of plagioclase [86,87]. Due to the relatively low ratios of $\mathrm{Ce} / \mathrm{Ce}^{*}$ for the zircons from sample 19-4s1 and 24-15s1, almost all the zircon grains plot in the field of low $f \mathrm{O}_{2}$ indicating that these formed in a lower $f \mathrm{O}_{2}$ environment (Figure 11a). Using the model proposed by [83], we also estimate the redox conditions for the samples 19-4s1 and 24-15s1 (Table S2 of Supplementary Materials), yielding the relatively low oxygen fugacities with $\log f \mathrm{O}_{2}$ values ranging from -19 to -15 (mean $=-17$ ) and from -19 to -13 (mean $=-15$ ), respectively. This data further confirmed that both the Indosinian and Yanshanian hydrothermal fluids are reducing fluids which are favorable for the W-Sn mineralization [88-91].

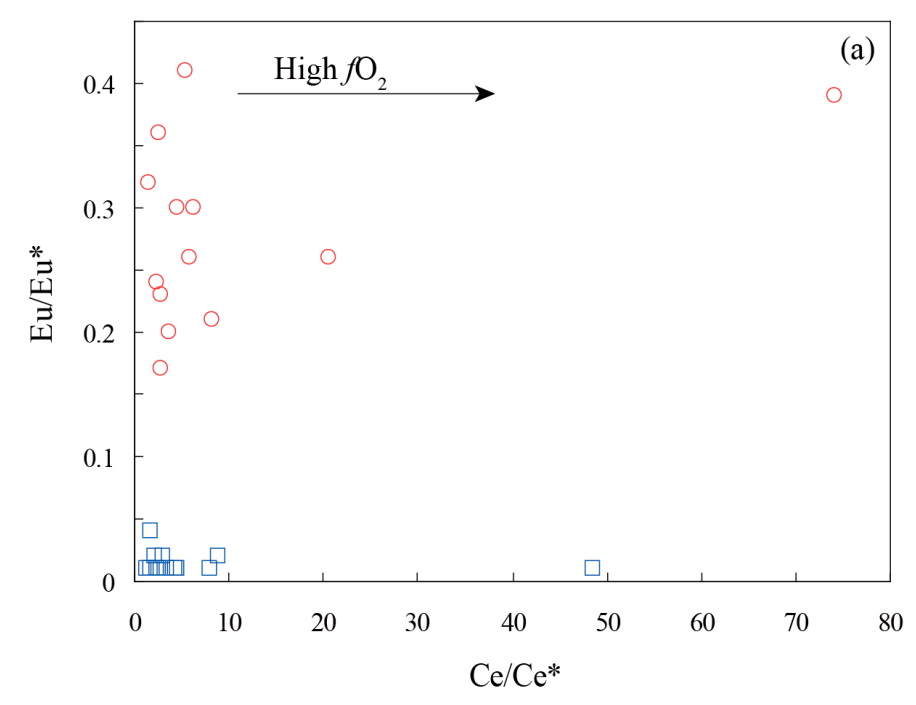

Figure 11. Cont. 


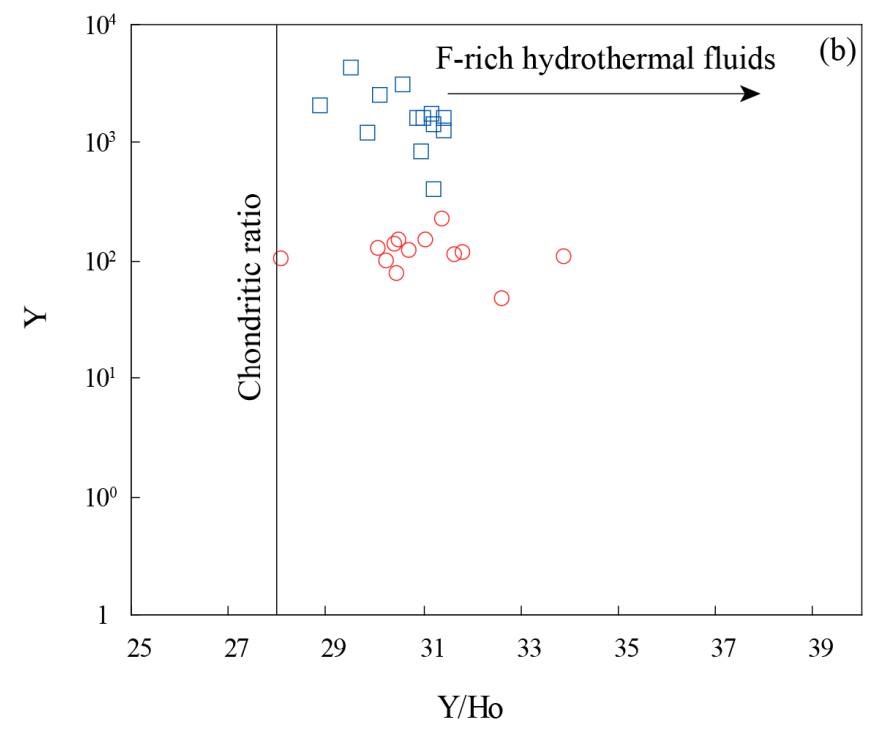

Figure 11. (a) Ce/Ce* versus $\mathrm{Eu} / \mathrm{Eu}^{*}$; and (b) $\mathrm{Y} / \mathrm{Ho}$ versus $\mathrm{Y}$ plots of zircon grains from the Xitian ore field. (b) is modified from [82]. Symbols are the same as those in Figure 7.

As an efficient tracer, $\mathrm{Y} / \mathrm{Ho}$ ratios can provide evidence about the chemical characteristics of source fluids [81]. Fractionation between the $\mathrm{Y}$ and Ho occurs in highly evolved granitic melts or hydrothermally altered granites with participation of F-rich fluids which contain high concentrations of $\mathrm{Y}, \mathrm{Li}, \mathrm{B}$, and/or P $[81,82,92,93]$. Zircon grains of the sample 19-4s1 and 24-15s1 are ranging from 28 to 34 (mean $=31)$ and from 29 to 31 (mean $=31)$, respectively, which are higher than the chondritic value of 28 (Figure 11a; [94]). The high ratios of zircons from these two samples suggest that they were crystallized in F-rich fluids, which are consistent with the existence of abundant fluorite ore bodies (Figure 11b).

\subsection{Source of Ore-Forming Metals}

On account of the extremely similar geochemical behavior, the REEs are always involved in the geological process in group, and the hydrothermal metamorphism will not change the composition mode and distribution mode of REEs in minerals or rocks, making them efficient tracers for determining the source rocks and element migration mechanism in ore-forming processes [95-98]. According to the chondrite-normalized REE patterns of Xitian skarns, they all show a good consistency, exhibiting right-dipping V-type curves with obvious negative Eu anomalies. Furthermore, the REE patterns of Xitian skarns are extremely similar to those of Xitian Indosinian granites, which are distinctly different to Yanshanian granites (Figure 10b; [28,38]). It indicates that the origin of skarn has a genetic relationship with Indosinian granites rather than Yanshanian granites. The Indosinian granitoids of the Xitian pluton are high-Si, high-K, weakly to strongly peraluminous, and highly fractionated S-type granites with high initial ${ }^{87} \mathrm{Sr} /{ }^{86} \mathrm{Sr}$ isotope ratios $(0.71397-0.71910)$, low $\varepsilon_{N d}(t)$ values ranging from -10.1 to -9.4 , and old Nd model ages (1858-1764 Ma), indicating that the Xitian Indosinian granites were mainly originated from partial melting of Paleoproterozoic metamorphic basement with small amounts of mantle-derived magma involved [38]. Since the Indosinian granites are closely related to the skarn type W-Sn mineralization, it can be inferred that the source of ore-forming metals from skarn type ore bodies should be mainly originated from a crustal source.

Radiogenic $\mathrm{Sr}, \mathrm{Nd}$, and $\mathrm{Pb}$ isotopes are powerful tools not only to determine magma sources, but also to determine ore-forming metals in minerals [99-103]. As the most important tungsten-bearing mineral in the tungsten deposit, geochemical compositions and mineralogical features of wolframite can provide abundant metallogenetic information, i.e., fluid, environment, and metal source $[1,5,44,104]$. The samples of wolframite analyzed in this study have high initial ${ }^{87} \mathrm{Sr} /{ }^{86} \mathrm{Sr}$ ratios 
(0.71282-0.72003), indicating that the wolframites in quartz vein type ore bodies are characterized by a crustal source. Furthermore, these samples also have negative $\varepsilon_{N d}(t)$ values ranging from -15.9 to -5.6 and cover a wide range of model ages $\left(\mathrm{T}_{\mathrm{DM} 2}=2168-1399 \mathrm{Ma}\right)$. In addition, almost all the samples are plotted near the evolution line of the Upper Continental Crust (UCC), and two samples are plotted in the field of the Meso-Paleoproterozoic low mature basement (Figure 12a), indicating that the ore-forming metals are mainly originated from the crustal source, which are proved by the diagram of age versus $\varepsilon_{\mathrm{Nd}}(\mathrm{t})$ (Figure 12b). Lead isotopic compositions of wolframites from the Xitian deposit are characterized by high radiogenic $\mathrm{Pb}$ isotope values with ${ }^{206} \mathrm{~Pb} /{ }^{204} \mathrm{~Pb}$ ratios of $18.489-18.569$, ${ }^{207} \mathrm{~Pb} /{ }^{204} \mathrm{~Pb}$ ratios of $15.724-15.877$, and ${ }^{208} \mathrm{~Pb} /{ }^{204} \mathrm{~Pb}$ ratios of $39.055-39.335$, and high values of $\mu$ ranging from 9.70 to 9.99 , indicating that $\mathrm{Pb}$ was derived from the upper crust. Additionally, the $\mathrm{Pb}$ isotopic compositions of the wolframites are similar to the sulfides of the quartz vein type ore bodies, and almost all the samples are plotted primarily toward the upper crust evolution field and/or line in the $\Delta \beta$ versus $\Delta \gamma$ and ${ }^{206} \mathrm{~Pb} /{ }^{204} \mathrm{~Pb}$ versus ${ }^{207} \mathrm{~Pb} /{ }^{204} \mathrm{~Pb}$ diagrams (Figure $12 \mathrm{c}, \mathrm{d}$ ). Briefly, based on the diagenetic and metallogenic geochronology, the relationship between the metallogenic and magmatic activities, and the evidence of mineral isotopes, we deduce that the ore-forming metals of quartz vein/greisen type ore bodies were also derived from a crustal source.
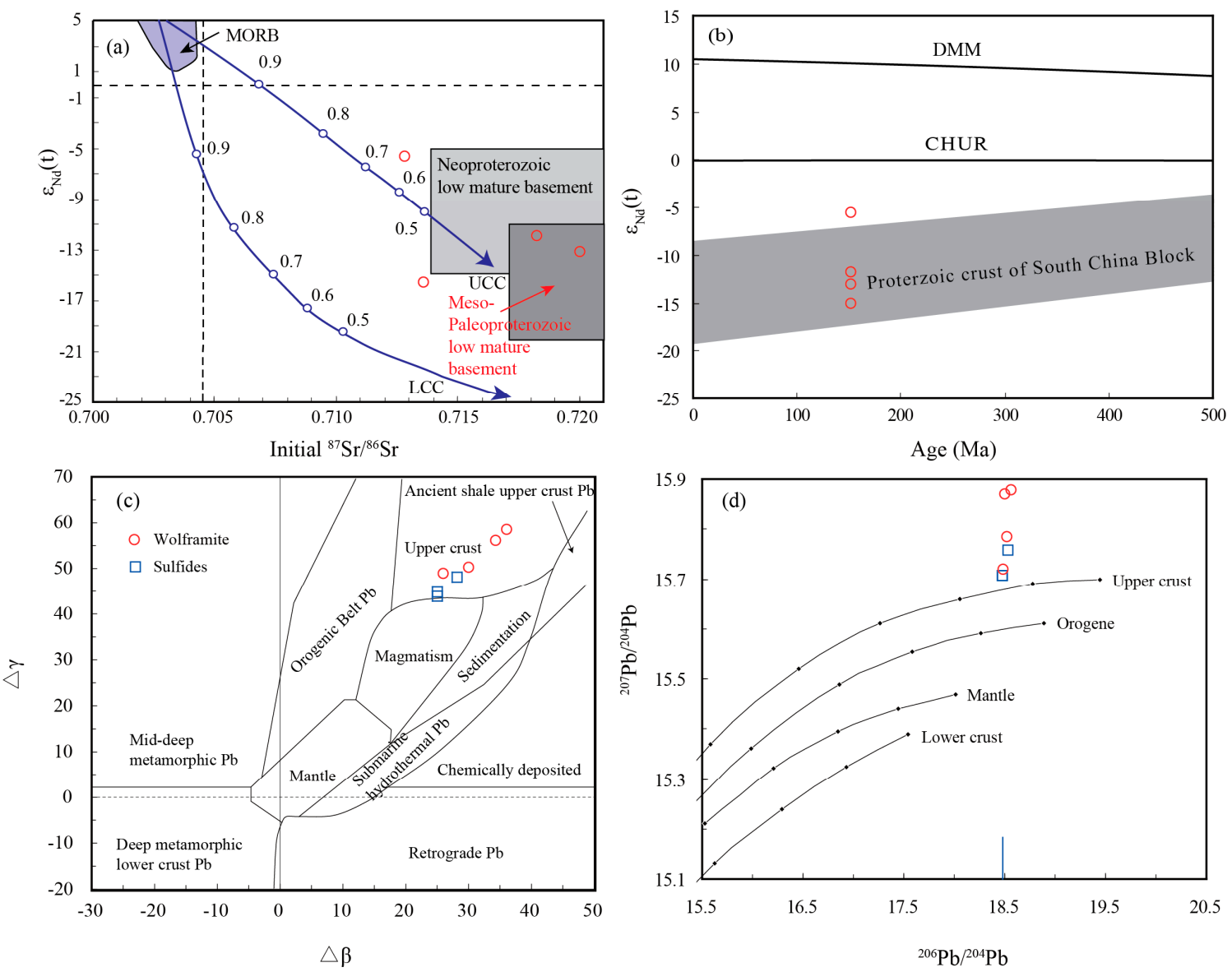

Figure 12. (a) Initial ${ }^{87} \mathrm{Sr} /{ }^{86} \mathrm{Sr}$ ratios versus $\varepsilon_{\mathrm{Nd}}(\mathrm{t})$; and (b) Age versus $\varepsilon_{\mathrm{Nd}}(\mathrm{t})$ plots for the wolframite from the Xitian ore field; (c) $\Delta \beta$ versus $\Delta \gamma$; and (d) ${ }^{206} \mathrm{~Pb} /{ }^{204} \mathrm{~Pb}$ versus ${ }^{207} \mathrm{~Pb} /{ }^{204} \mathrm{~Pb}$ diagrams for the wolframite from the Xitian ore field. (a-d) are modified from $[59,78,105,106]$. Data of sulfides are from [107]. MORB: Mid Ocean Ridge Basalt; DMM: depleted end-member; CHUR: chondritic uniform reservoir. 


\section{Conclusions}

1. Hydrothermal zircon $\mathrm{U}-\mathrm{Pb}$ and muscovite ${ }^{40} \mathrm{Ar} /{ }^{39} \mathrm{Ar}$ dating suggests that there are two epochs of W-Sn mineralization in the Xitian ore field, with skarn-type W-Sn mineralization at ca. $226 \mathrm{Ma}$ and quartz vein/greisen type W-Sn mineralization at ca. $156 \mathrm{Ma}$.

2. The ore-forming fluids for the two metallogenic events are both characterized by enrichment in $\mathrm{F}$ and low oxygen fugacities.

3. The ore-forming metals for the skarn-type and quartz vein/greisen type W-Sn mineralization are both originated from a crust source.

Supplementary Materials: The following are available online at http:/ /www.mdpi.com/2075-163x/8/3/111/s1, Table S1: LA-ICP-MS zircon U-Pb isotopic compositions of altered granite in Xitian W-Sn ore field, Table S2: LA-ICP-MS zircon trace element compositions of altered granite in Xitian W-Sn ore field (ppm), Table S3: ${ }^{40} \mathrm{Ar} /{ }^{39} \mathrm{Ar}$ laser stepwise heating analytical data for two muscovite samples from the Xitian W-Sn ore field, Table S4: Major and trace element compositions of the skarn in Xitian W-Sn ore field, Table S5: Sr-Nd-Pb isotopic compositions of wolframite in Xitian W-Sn ore field, Table S6: Synthesis of the metallogenic ages of the W-Sn deposits associated with the granitic pluton in the Nanling range.

Acknowledgments: This study was financially supported by the China Geological Survey (Grant No. 12120114052101), the National Key R\&D Program of China (No. 2016YFC0600404) and the National Natural Science Foundation of China (Nos. 41673040, 41502067). The manuscript has been greatly benefited from constructive comments by Editors-in-Chief Paul Sylvester, and other two anonymous reviewers. It has also been significantly improved in both English and science by Lei Liu of the University of Science and Technology of China. Editor Ms. Queenie Wang is also appreciated for their helpful suggestions.

Author Contributions: Jingya Cao, and Qianhong Wu conceived and designed the experiments; Hua Kong and Xiaoshuang Xi took part to the field campaigns; Huan Li took part in the discussion; Qianfeng Huang and Biao Liu analyzed the data; Jingya Cao, Qianhong Wu and Xiaoyong Yang wrote the paper.

Conflicts of Interest: The authors declare no conflict of interest.

\section{References}

1. Kempe, U.; Wolf, D. Anomalously high Sc contents in ore minerals from Sn-W deposits: Possible economic significance and genetic implications. Ore Geol. Rev. 2006, 28, 103-122. [CrossRef]

2. Mao, J.W.; Xie, G.Q.; Guo, C.L.; Chen, Y.C. Large-scale tungsten-tin mineralization in the Nanling region, South China: Metallogenic ages and corresponding geodynamic processes. Acta Petrol. Sin. 2007, 23, 2329-2338. (In Chinese)

3. Mao, J.W.; Xie, G.Q.; Guo, C.L.; Yuan, S.D.; Cheng, Y.B.; Chen, Y.C. Spatial-temporal distribution of Mesozoic ore deposits in south China and their metallogenic settings. Geol. J. Chin. Univ. 2008, 14, 510-526. (In Chinese)

4. Mao, J.; Pirajno, F.; Cook, N. Mesozoic metallogeny in East China and corresponding geodynamic settings-An introduction to the special issue. Ore Geol. Rev. 2011, 43, 1-7. [CrossRef]

5. Neiva, A.M.R. Geochemistry of cassiterite and wolframite from tin and tungsten quartz veins in Portugal. Ore Geol. Rev. 2008, 33, 221-238. [CrossRef]

6. Moura, A.; Dória, A.; Neiva, A.M.R.; Leal Gomes, C.; Creaser, R.A. Metallogenesis at the Carris W-Mo-Sn deposit (Gerês, Portugal): Constraints from fluid inclusions, mineral geochemistry, Re-Os and He-Ar isotopes. Ore Geol. Rev. 2014, 56, 73-93. [CrossRef]

7. Cheng, Y.; Mao, J.; Liu, P. Geodynamic setting of Late Cretaceous Sn-W mineralization in southeastern Yunnan and northeastern Vietnam. Solid Earth Sci. 2016, 1, 79-88. [CrossRef]

8. Chicharro, E.; Boiron, M.; López-García, J.Á.; Barfod, D.N.; Villaseca, C. Origin, ore forming fluid evolution and timing of the Logrosán Sn-(W) ore deposits (Central Iberian Zone, Spain). Ore Geol. Rev. 2016, 72, 896-913. [CrossRef]

9. Liu, P.; Mao, J.; Cheng, Y.; Yao, W.; Wang, X.; Hao, D. An Early Cretaceous W-Sn deposit and its implications in southeast coastal metallogenic belt: Constraints from U-Pb, Re-Os, Ar-Ar geochronology at the Feie'shan W-Sn deposit, SE China. Ore Geol. Rev. 2017, 81, 112-122. [CrossRef]

10. Soloviev, S.G.; Kryazhev, S.G.; Dvurechenskaya, S.S. Geology, mineralization, stable isotope, and fluid inclusion characteristics of the Vostok-2 reduced W-Cu skarn and Au-W-Bi-As stockwork deposit, Sikhote-Alin, Russia. Ore Geol. Rev. 2017, 86, 338-365. [CrossRef] 
11. Soloviev, S.G.; Kryazhev, S.G.; Dvurechenskaya, S.S. Geology, mineralization, and fluid inclusion characteristics of the Lermontovskoe reduced-type tungsten $(\mathrm{Cu}, \mathrm{Au}, \mathrm{Bi})$ skarn deposit, Sikhote-Alin, Russia. Ore Geol. Rev. 2017, 89, 15-39. [CrossRef]

12. Zhang, Y.; Yang, J.; Chen, J.; Wang, H.; Xiang, Y. Petrogenesis of Jurassic tungsten-bearing granites in the Nanling Range, South China: Evidence from whole-rock geochemistry and zircon U-Pb and Hf-O isotopes. Lithos 2017, 278, 166-180. [CrossRef]

13. Zhao, W.W.; Zhou, M.; Li, Y.H.M.; Zhao, Z.; Gao, J. Genetic types, mineralization styles, and geodynamic settings of Mesozoic tungsten deposits in South China. J. Asian Earth Sci. 2017, 137, 109-140. [CrossRef]

14. U.S. Geological Survey. Mineral Commodity Summaries 2016; U.S. Geological Survey: Reston, VA, USA, 2016; p. 202.

15. Wang, D.H.; Chen, Y.C.; Chen, Z.H.; Liu, S.B.; Xu, J.X.; Zhang, J.J.; Zeng, Z.L.; Chen, F.W.; Li, H.Q.; Guo, C.L. Assessment on mineral resource in Nanling region and suggestion for further prospecting. Acta Geol. Sin. 2007, 81, 882-890. (In Chinese)

16. Chen, J.; Wang, R.; Zhu, J.; Lu, J.; Ma, D. Multiple-aged granitoids and related tungsten-tin mineralization in the Nanling Range, South China. Sci. China-Earth Sci. 2013, 56, 2045-2055. (In Chinese) [CrossRef]

17. Guo, C.; Mao, J.; Bierlein, F.; Chen, Z.; Chen, Y.; Li, C.; Zeng, Z. SHRIMP U-Pb (zircon), Ar-Ar (muscovite) and Re-Os (molybdenite) isotopic dating of the Taoxikeng tungsten deposit, South China Block. Ore Geol. Rev. 2011, 43, 26-39. [CrossRef]

18. Hu, R.; Wei, W.; Bi, X.; Peng, J.; Qi, Y.; Wu, L.; Chen, Y. Molybdenite Re-Os and muscovite Ar-40/Ar-39 dating of the Xihuashan tungsten deposit, central Nanling district, South China. Lithos 2012, 150, 111-118. [CrossRef]

19. Liang, X.; Dong, C.; Jiang, Y.; Wu, S.; Zhou, Y.; Zhu, H.; Fu, J.; Wang, C.; Shan, Y. Zircon U-Pb, molybdenite Re-Os and muscovite Ar-Ar isotopic dating of the Xitian W-Sn polymetallic deposit, eastern Hunan Province, South China and its geological significance. Ore Geol. Rev. 2016, 78, 85-100. [CrossRef]

20. Mao, J.; Cheng, Y.; Chen, M.; Pirajno, F. Major types and time-space distribution of Mesozoic ore deposits in South China and their geodynamic settings. Miner. Deposita 2013, 48, 267-294.

21. Peng, J.; Zhou, M.; Hu, R.; Shen, N.; Yuan, S.; Bi, X.; Du, A.; Qu, W. Precise molybdenite Re-Os and mica Ar-Ar dating of the Mesozoic Yaogangxian tungsten deposit, central Nanling district, South China. Miner. Deposita 2006, 41, 661-669. [CrossRef]

22. Yao, Y.; Chen, J.; Lu, J.; Wang, R.; Zhang, R. Geology and genesis of the Hehuaping magnesian skarn-type cassiterite-sulfide deposit, Hunan Province, Southern China. Ore Geol. Rev. 2014, 58, 163-184. [CrossRef]

23. Chen, Y.; Li, H.; Sun, W.; Ireland, T.; Tian, X.; Hu, Y.; Yang, W.; Chen, C.; Xu, D. Generation of Late Mesozoic Qianlishan A2-type granite in Nanling Range, South China: Implications for Shizhuyuan W-Sn mineralization and tectonic evolution. Lithos 2016, 266-267, 435-452. [CrossRef]

24. Yuan, S.; Peng, J.; Hu, R.; Li, H.; Shen, N.; Zhang, D. A precise U-Pb age on cassiterite from the Xianghualing tin-polymetallic deposit (Hunan, South China). Miner. Deposita 2008, 43, 375-382. [CrossRef]

25. Zhang, W.; Hua, R.; Wang, R.; Chen, P.; Li, H. New dating of Dajishan granite and related tungsten mineralization, South Jiangxi Province, China. Front. Earth Sci. 2007, 1, 218-225. [CrossRef]

26. Dong, S.H.; Bi, X.W.; Hu, R.Z.; Chen, Y.W. Petrogenesis of Yaogangxian granites and inplications for W mineralization, Hunan province. Acta Petrol. Sin. 2014, 30, 2749-2765. (In Chinese)

27. Guo, C.; Chen, Y.; Zeng, Z.; Lou, F. Petrogenesis of the Xihuashan granites in southeastern China: Constraints from geochemistry and in-situ analyses of zircon U-Pb-Hf-O isotopes. Lithos 2012, 148, 209-227. [CrossRef]

28. Zhou, Y.; Liang, X.; Wu, S.; Cai, Y.; Liang, X.; Shao, T.; Wang, C.; Fu, J.; Jiang, Y. Isotopic geochemistry, zircon $\mathrm{U}-\mathrm{Pb}$ ages and $\mathrm{Hf}$ isotopes of A-type granites from the Xitian W-Sn deposit, SE China: Constraints on petrogenesis and tectonic significance. J. Asian Earth Sci. 2015, 105, 122-139. [CrossRef]

29. Li, X.H.; Liu, D.Y.; Sun, M.; Li, W.X.; Liang, X.R.; Liu, Y. Precise Sm-Nd and U-Pb isotopic dating of the supergiant Shizhuyuan polymetallic deposit and its host granite, SE China. Geol. Mag. 2004, 141, $225-231$. [CrossRef]

30. Zhang, S.M.; Chen, Z.H.; Shi, G.H.; Li, L.X.; Qu, W.J.; Li, C. Re-Os isotopic dating of molybdenite from Dajishan tungsten deposit in Jiangxi Province. Miner. Depos. 2011, 30, 1113-1121. (In Chinese) 
31. Zhang, R.; Lu, J.; Wang, R.; Yang, P.; Zhu, J.; Yao, Y.; Gao, J.; Li, C.; Lei, Z.; Zhang, W. Constraints of in situ zircon and cassiterite $\mathrm{U}-\mathrm{Pb}$, molybdenite Re-Os and muscovite Ar-40-Ar-39 ages on multiple generations of granitic magmatism and related W-Sn mineralization in the Wangxianling area, Nanling Range, South China. Ore Geol. Rev. 2015, 65, 1021-1042. [CrossRef]

32. Cai, M.H.; Chen, K.X.; Chen, K.X.; Liu, G.Q.; Fu, J.M.; Yin, J.P. Geological characteristics and Re-Os dating of molybdenites in Hehuaping tin-polymetallic deposit, Southern Hunan Province. Miner. Depos. 2006, 25, 263-268. (In Chinese)

33. Yang, F.; Li, X.F.; Feng, Z.H.; Bai, Y. 40Ar/39Ar dating of muscovite from greisenized granite and geological significance in Limu tin deposit. J. Guilin Univ. Technol. 2009, 29, 21-24. (In Chinese)

34. Cai, Y.; Ma, D.S.; Lu, J.J.; Huang, H.; Zhang, R.Q.; Qu, W.J. Re-Os geochronology and S isotope geochemistry of Dengfuxian tungsten deposit, Hunan Province, China. Acta Petrol. Sin. 2012, 28, 3798-3808. (In Chinese)

35. Li, X.H.; Chung, S.L.; Zhou, H.W.; Lo, C.H.; Liu, Y.; Chen, C.W. Jurassic intraplate magmatism in southern Hunan-eastern Guangxi: Ar-40/Ar-39 dating, geochemistry, Sr-Nd isotopes and implications for the tectonic evolution of SE China. Geol. Soc. Spec. Publ. 2004, 226, 193-215. [CrossRef]

36. Li, X.; Xiao, R.; Feng, Z.; Chunxia, W.; Tang, Y.; Bai, Y.; Zhang, M. Ar-Ar ages of hydrothermal muscovite and igneous biotite at the Guposhan-Huashan district, Northeast Guangxi, South China: Implications for mesozoic W-Sn mineralization. Resour. Geol. 2015, 65, 160-176. [CrossRef]

37. Yuan, S.; Peng, J.; Shen, N.; Hu, R.; Dai, T. Ar-40-Ar-39 isotopic dating of the Xianghualing Sn-polymetallic ore field in southern Hunan, China and its geological implications. Acta Geol. Sin. Engl. 2007, 81, 278-286.

38. Wu, Q.; Cao, J.; Kong, H.; Shao, Y.; Li, H.; Xi, X.; Deng, X. Petrogenesis and tectonic setting of the early Mesozoic Xitian granitic pluton in the middle Qin-Hang Belt, South China: Constraints from zircon U-Pb ages and bulk-rock trace element and Sr-Nd-Pb isotopic compositions. J. Asian Earth Sci. 2016, 128, 130-148. [CrossRef]

39. Xiong, Y.; Shao, Y.; Zhou, H.; Wu, Q.; Liu, J.; Wei, H.; Zhao, R.; Cao, J. Ore-forming mechanism of quartz-vein-type W-Sn deposits of the Xitian district in SE China: Implications from the trace element analysis of wolframite and investigation of fluid inclusions. Ore Geol. Rev. 2017, 83, 152-173. [CrossRef]

40. Guo, C.L.; Li, C.; Wu, S.C.; Xu, Y.M. Molybdenite Re-Os Isotopic Dating of Xitian Deposit in Hunan Province and Its Geological Significance. Rock Miner. Anal. 2014, 33, 142-152. (In Chinese)

41. Ma, L.Y.; Fu, J.M.; Wu, S.C.; Xu, D.M.; Yang, X.J. 40Ar/39Ar isotopic dating of the Longshang tin-polymetallic deposit, Xitian ore field, eastern Hunan. Geol. Chin. 2008, 35, 706-713. (In Chinese)

42. Wang, M.; Bai, X.J.; Hu, R.G.; Cheng, S.B.; Pu, Z.P.; Qiu, H.N. Direct dating of cassiterite in Xitian Tungsten-Tin polymetallic deposit, South-East Hunan, by 40Ar/39Ar Progressive Crushing. Geotecton. Metallog. 2015, 39, 1049-1060. (In Chinese)

43. Deng, X.W.; Liu, J.X.; Dai, X.L. Geological characteristics and molybdenite Re-Os isotopic age of Hejiangkou tungsten and tin polymetallic deposit, East Hunan, China. Chin. J. Nonferrous Met. 2015, 25, 2883-2897. (In Chinese)

44. Xiong, Y.Q.; Shao, Y.J.; Liu, J.P.; Wei, H.T.; Zhao, R.C. Ore-forming fluid of quartz-vein type tungsten deposits, Xitian ore field, eastern Hunan, China. Chin. J. Nonferrous Met. 2016, 26, 1107-1119. (In Chinese)

45. Zhao, J.; Zhou, M.; Yan, D.; Zheng, J.; Li, J. Reappraisal of the ages of Neoproterozoic strata in South China: No connection with the Grenvillian orogeny. Geology 2011, 39, 299-302. [CrossRef]

46. Yu, C. The characteristic target-pattern regional ore zonality of the Nanling region, China (I). Geosci. Front. 2011, 2, 147-156. [CrossRef]

47. Mao, J.; Takahashi, Y.; Kee, W.; Li, Z.; Ye, H.; Zhao, X.; Liu, K.; Zhou, J. Characteristics and geodynamic evolution of Indosinian magmatism in South China: A case study of the Guikeng pluton. Lithos 2011, 127, 535-551. [CrossRef]

48. Mao, J.; Ye, H.; Liu, K.; Li, Z.; Takahashi, Y.; Zhao, X.; Kee, W. The Indosinian collision-extension event between the South China Block and the Palaeo-Pacific plate: Evidence from Indosinian alkaline granitic rocks in Dashuang, eastern Zhejiang, South China. Lithos 2013, 172-173, 81-97. [CrossRef]

49. Niu, Y.; Liu, Y.; Xue, Q.; Shao, F.; Chen, S.; Duan, M.; Guo, P.; Gong, H.; Hu, Y.; Hu, Z. Exotic origin of the Chinese continental shelf: New insights into the tectonic evolution of the western Pacific and eastern China since the Mesozoic. Sci. Bull. 2015, 60, 1598-1616. [CrossRef] 
50. Wang, Y.; Fan, W.; Sun, M.; Liang, X.; Zhang, Y.; Peng, T. Geochronological, geochemical and geothermal constraints on petrogenesis of the Indosinian peraluminous granites in the South China Block: A case study in the Hunan Province. Lithos 2007, 96, 475-502. [CrossRef]

51. Wang, Y.; Fan, W.; Zhang, G.; Zhang, Y. Phanerozoic tectonics of the South China Block: Key observations and controversies. Gondwana Res. 2013, 23, 1273-1305. [CrossRef]

52. Yan, Q.; Shi, X.; Castillo, P.R. The late Mesozoic-Cenozoic tectonic evolution of the South China Sea: A petrologic perspective. J. Asian Earth Sci. 2014, 85, 178-201. [CrossRef]

53. Zhang, G.; Guo, A.; Wang, Y.; Li, S.; Dong, Y.; Liu, S.; He, D.; Cheng, S.; Lu, R.; Yao, A. Tectonics of South China continent and its implications. Sci. China Earth Sci. 2013, 56, 1804-1828. [CrossRef]

54. Hua, R.M.; Chen, P.R.; Zhang, W.L.; Liu, X.D.; Lu, J.J.; Lin, J.F.; Yao, J.M.; Q1, H.W.; Zhang, Z.; Gu, S.Y. Metallogenic systems related to Mesozoic and Cenozoic granitoids in South China. Sci. China Earth Sci. 2003, 46, 816-829. [CrossRef]

55. Hua, R.M.; Zhang, W.L.; Gu, S.Y.; Chen, P.R. Comparison between REE granites and W-Sn granite in the Nanling region, South China, and their mineralizations. Acta Petrol. Sin. 2007, 23, 2321-2328. (In Chinese)

56. Fan, W.M.; Wang, Y.J.; Guo, F.; Peng, T.P. Mesozoic mafic magmatism in Hunan-Jiangxi province and the lithospheric extension. Earth Sci. Front. 2003, 10, 159-169. (In Chinese)

57. Li, J.G.; Li, J.K.; Wang, D.H.; Liu, J.; He, H.H. The deep tectonic features of Qitianling ore-concentrated area in Southern Hunan province and its contrains to the regional ore-forming process. Acta Geol. Sin. 2014, 88, 695-703. (In Chinese)

58. Cai, Y.; Lu, J.; Ma, D.; Huang, H.; Zhang, H.; Zhang, R. The Late Triassic Dengfuxian A-type granite, Hunan Province: Age, petrogenesis, and implications for understanding the late Indosinian tectonic transition in South China. Int. Geol. Rev. 2015, 57, 428-445. [CrossRef]

59. Guo, C.; Zeng, L.; Li, Q.; Fu, J.; Ding, T. Hybrid genesis of Jurassic fayalite-bearing felsic subvolcanic rocks in South China: Inspired by petrography, geochronology, and Sr-Nd-O-Hf isotopes. Lithos 2016, 264, 175-188. [CrossRef]

60. Wu, S.C.; Long, Z.Q.; Xu, H.H.; Zhou, Y.; Jiang, Y.; Pan, C.C. Structural characteristics and prospecting significance of the Xitian tin-tungsten polymetallic deposit, Hunan province, China. Geotecton. Metallog. 2012, 36, 217-226. (In Chinese)

61. Bureau of Geology and Mineral Resources of Hunan Province. Regional Geology of the Hunan Province; Geological Publishing House: Beijing, China, 1988; p. 507. (In Chinese)

62. Wang, Y.J.; Fan, W.M.; Guo, F.; Peng, T.P.; Li, C.W. Geochemistry of Mesozoic mafic rocks adjacent to the Chenzhou-Linwu fault, South China: Implications for the lithospheric boundary between the Yangtze and Cathaysia blocks. Int. Geol. Rev. 2003, 45, 263-286. [CrossRef]

63. Chen, D.; Ma, A.J.; Liu, W.; Liu, Y.R.; Ni, Y.J. Research on U-Pb Chronology in Xitian pluton of Hunan province. Geoscience 2013, 27, 819-830. (In Chinese)

64. Wiedenbeck, M.; Alle, P.; Corfu, F.; Griffin, W.L.; Meier, M.; Ober, F.; Von Quadt, A.; Roddick, J.C.; Speigel, W. Three natural zircon standards for U-Th- $\mathrm{Pb}, \mathrm{Lu}-\mathrm{Hf}$, trace-element and REE analyses. Geostand. Geoanal. Res. 1995, 19, 1-23. [CrossRef]

65. Elhlou, S.; Belousova, E.; Griffin, W.L.; Pearson, N.J.; O Reilly, S.Y. Trace element and isotopic composition of GJ-red zircon standard by laser ablation. Geochim. Cosmochim. Acta 2006, 70, A158. [CrossRef]

66. Liu, Y.; Gao, S.; Hu, Z.; Gao, C.; Zong, K.; Wang, D. Continental and oceanic crust recycling-induced melt-peridotite interactions in the trans-north china orogen: $\mathrm{U}-\mathrm{Pb}$ dating, Hf isotopes and trace elements in Zircons from mantle xenoliths. J. Petrol. 2010, 51, 537-571. [CrossRef]

67. Andersen, T. Correction of common lead in U-Pb analyses that do not report 204Pb. Chem. Geol. 2002, 192, 59-79. [CrossRef]

68. Ludwig, K.R. ISOPLOT 3.00: A Geochronological Toolkit for Microsoft Excel; Berkeley Geochronology Center: Berkeley, CA, USA, 2003; p. 39.

69. Wang, S.S. Age determinations of 40Ar-40K, 40Ar-40Ar and radiogenic 40Ar released characteristics on $\mathrm{K}-\mathrm{Ar}$ geostandards of China. Chin. J. Geol. 1983, 4, 315-323. (In Chinese)

70. Qiu, H.N.; Bai, X.J.; Liu, W.G.; Mei, L.F. Automatic 40Ar/39Ar dating technique using multicollector ArgusVI MS with home-made apparatus. Geochimica 2015, 44, 477-484. (In Chinese)

71. Koppers, A. ArArCALC-software for Ar-40/Ar-39 age calculations. Comput. Geosci. 2002, 28, 605-619. [CrossRef] 
72. Chen, F.; Siebel, W.; Satir, M.; Lu, M.T.; Saka, K. Geochronology of the Karadere basement (NW Turkey) and implications for the geological evolution of the Istanbul zone. Int. J. Earth Sci. 2002, 91, 469-481. [CrossRef]

73. Hoskin, P.; Schaltegger, U. The composition of zircon and igneous and metamorphic petrogenesis. Rev. Miner. Geochem. 2003, 53, 27-62. [CrossRef]

74. Taylor, S.R.; McLennan, S.M. Continental Crust: Its Composition and Evolution: An Examination of the Geochemical Record Preserved in Sedimentary Rocks; Blackwell Scientific: Hoboken, NJ, USA, 1985; p. 312.

75. Hoskin, P. Trace-element composition of hydrothermal zircon and the alteration of Hadean zircon from the Jack Hills, Australia. Geochim. Cosmochim. Acta 2005, 69, 637-648. [CrossRef]

76. Sun, S.S.; McDonough, W.F. Chemical and isotopic systematics of oceanic basalts: Implications for mantle compositions and processes. In Magmatism in the Ocean Basins; Saunders, A.D., Norry, M.J., Eds.; Geological Society, London Special Publication: London, UK, 1989; Volume 32, pp. 313-345.

77. Zartman, R.E.; Doe, B.R. Plumbotectonics-The model. Tectonophysics 1981, 75, 135-162. [CrossRef]

78. Liu, G.Q.; Wu, S.C.; Du, A.D.; Fu, J.M.; Yang, X.J.; Tang, Z.H.; Wei, J.Q. Metallogenic ages of the Xitian tungsten-tin deposit, Eastern Hunan Province. Geotecton. Metallog. 2008, 32, 63-71. (In Chinese)

79. Hua, R.M.; Mao, J.W. A preliminary discussion on the Mesozoic metallogenic explosion in East China. Miner. Depos. 1999, 18, 300-308. (In Chinese)

80. Ferry, J.M.; Watson, E.B. New thermodynamic models and revised calibrations for the Ti-in-zircon and Zr-in-rutile thermometers. Contrib. Miner. Petrol. 2007, 154, 429-437. [CrossRef]

81. Irber, $\mathrm{W}$. The lanthanide tetrad effect and its correlation with $\mathrm{K} / \mathrm{Rb}, \mathrm{Eu} / \mathrm{Eu}^{*}, \mathrm{Sr} / \mathrm{Eu}, \mathrm{Y} / \mathrm{Ho}$, and $\mathrm{Zr} \mathrm{Hf}$ of evolving peraluminous granite suites. Geochim. Cosmochim. Acta 1999, 63, 489-508. [CrossRef]

82. Kozlik, M.; Raith, J.G.; Gerdes, A. U-Pb, Lu-Hf and trace element characteristics of zircon from the Felbertal scheelite deposit (Austria): New constraints on timing and source of W mineralization. Chem. Geol. 2016, 421, 112-126. [CrossRef]

83. Trail, D.; Watson, E.B.; Tailby, N.D. Ce and Eu anomalies in zircon as proxies for the oxidation state of magmas. Geochim. Cosmochim. Acta 2012, 97, 70-87. [CrossRef]

84. Trail, D.; Watson, E.B.; Tailby, N.D. The oxidation state of Hadean magmas and implications for early Earth's atmosphere. Nature 2011, 480, 79-238. [CrossRef] [PubMed]

85. Li, H.; Watanabe, K.; Yonezu, K. Zircon morphology, geochronology and trace element geochemistry of the granites from the Huangshaping polymetallic deposit, South China: Implications for the magmatic evolution and mineralization processes. Ore Geol. Rev. 2014, 60, 14-35. [CrossRef]

86. Burnham, A.D.; Berry, A.J. An experimental study of trace element partitioning between zircon and melt as a function of oxygen fugacity. Geochim. Cosmochim. Acta 2012, 95, 196-212. [CrossRef]

87. Kong, D.; $\mathrm{Xu}, \mathrm{J} . ;$ Chen, J. Oxygen isotope and trace element geochemistry of zircons from porphyry copper system: Implications for Late Triassic metallogenesis within the Yidun Terrane, southeastern Tibetan Plateau. Chem. Geol. 2016, 441, 148-161. [CrossRef]

88. Bhalla, P.; Holtz, F.; Linnen, R.L.; Behrens, H. Solubility of cassiterite in evolved granitic melts: Effect of $T$, $\mathrm{fO}_{2}$, and additional volatiles. Lithos 2005, 80, 387-400. [CrossRef]

89. Lehmann, B. Metallogeny of Tin; Lecture Notes in Earth Sciences Berlin Springer Verlag: Berlin, Germany, 1990; Volume 32, p. 211.

90. Li, X.; Chi, G.; Zhou, Y.; Deng, T.; Zhang, J. Oxygen fugacity of Yanshanian granites in South China and implications for metallogeny. Ore Geol. Rev. 2017, 88, 690-701. [CrossRef]

91. Linnen, R.L.; Pichavant, M.; Holtz, F. The combined effects of $f \mathrm{O}_{2}$ and melt composition on $\mathrm{SnO}_{2}$ solubility and tin diffusivity in haplo-granitic melts. Geochim. Cosmochim. Acta 1996, 60, 4965-4976. [CrossRef]

92. Bau, M. Controls on the fractionation of isovalent trace elements in magmatic and aqueous systems: Evidence from $\mathrm{Y} / \mathrm{Ho}, \mathrm{Zr} / \mathrm{Hf}$, and lanthanide tetrad effect. Contrib. Miner. Petrol. 1996, 123, 323-333. [CrossRef]

93. Veksler, I.V.; Dorfman, A.M.; Kamenetsky, M.; Dulski, P.; Dingwell, D.B. Partitioning of lanthanides and Y between immiscible silicate and fluoride melts, fluorite and cryolite and the origin of the lanthanide tetrad effect in igneous rocks. Geochim. Cosmochim. Acta 2005, 69, 2847-2860. [CrossRef]

94. Anders, E.; Grevesse, N. Abundances of the elements: Meteoritic and solar. Geochim. Cosmochim. Acta 1989, 53, 197-214. [CrossRef]

95. Bau, M. Rare-earth element mobility during hydrothermal and metamorphic fluid-rock interaction and the significance of the oxidation state of europium. Chem. Geol. 1991, 93, 219-230. [CrossRef] 
96. Boulvais, P.; Fourcade, S.; Moine, B.; Gruau, G.; Cuney, M. Rare-earth elements distribution in granulite-facies marbles: A witness of fluid-rock interaction. Lithos 2000, 53, 117-126. [CrossRef]

97. Chen, L.; Qin, K.Z.; Li, G.M.; Xiao, B.; Li, J.X.; Jiang, H.Z.; Chen, J.B.; Zhao, J.X.; Fan, X.; Han, F.J. Geochemical characteristics and origin of skarn rocks in the Nuri Cu-Mo-W deposit, Southern Tibet. Geol. Explor. 2011, 47, 78-88. (In Chinese)

98. Zamanian, H.; Radmard, K. Geochemistry of rare earth elements in the baba Ali magnetite skarn deposit, western Iran-a key to determine conditions of mineralisation. Geologos 2016, 22, 33-47. [CrossRef]

99. Jahn, B.; Valui, G.; Kruk, N.; Gonevchuk, V.; Usuki, M.; Wu, J.T.J. Emplacement ages, geochemical and Sr-Nd-Hf isotopic characterization of Mesozoic to early Cenozoic granitoids of the Sikhote-Alin Orogenic Belt, Russian Far East: Crustal growth and regional tectonic evolution. J. Asian Earth Sci. 2015, 111, 872-918. [CrossRef]

100. Pankhurst, M.J.; Vernon, R.H.; Turner, S.P.; Schaefer, B.F.; Foden, J.D. Contrasting Sr and Nd isotopic behaviour during magma mingling; new insights from the Mannum A-type granite. Lithos 2011, 126, 135-146. [CrossRef]

101. Volkert, R.A.; Feigenson, M.D.; Mana, S.; Bolge, L. Geochemical and Sr-Nd isotopic constraints on the mantle source of Neoproterozoic mafic dikes of the rifted eastern Laurentian margin, north-central Appalachians, USA. Lithos 2015, 212-215, 202-213. [CrossRef]

102. Xiong, D.X.; Sun, X.M.; Shi, G.Y.; Wang, S.W.; Gao, J.F.; Xu, T. Trace elements, rare earth elements (REE) and $\mathrm{Nd}-\mathrm{Sr}$ isotopic compositions in scheelites and their implications for the mineralization in Daping gold mine in Yunnan province, China. Acta Petrol. Sin. 2006, 22, 733-741. (In Chinese)

103. Zhang, Z.; Zuo, R. Sr-Nd-Pb isotope systematics of magnetite: Implications for the genesis of Makeng Fe deposit, southern China. Ore Geol. Rev. 2014, 57, 53-60. [CrossRef]

104. Tindle, A.G.; Webb, P.C. Niobian wolframite from Glen Gairn in the Eastern Highland of Scotland-A microprobe investigation. Geochim. Cosmochim. Acta 1989, 53, 1921-1935. [CrossRef]

105. Sun, T.; Zhou, X.M.; Chen, P.R.; Li, H.M.; Zhou, H.Y.; Wang, Z.C.; Shen, W.Z. Petrogenesis of Mesozoic strongly peraluminous granites in the Nanling, China. Sci. China Earth Sci. 2003, 33, 1209-1218. (In Chinese)

106. Zhu, B.Q.; Li, X.H.; Dai, T.M. Theory and Application of Isotope Systematics in Earth Sciences; Science Press: Beijing, China, 1998; p. 333. (In Chinese)

107. Yao, Y. Magnesian and Calcic Skarn Type Tin-Polymetallic Mineralization in the Nanling Range: Case Study from Hehuaping and Xitian. Ph.D. Thesis, Nanjing University, Nanjing, China, 2012. (In Chinese) 